\title{
A radiogenic isotopic (He-Sr-Nd-Pb-Os) study of lavas from the Pitcairn hotspot: Implications for the origin of EM-1 (enriched mantle 1)
}

\author{
G. Garapića, ${ }^{a}$, M.G. Jackson ${ }^{\text {a }}$, E.H.Hauri ${ }^{\mathrm{b}}$, S.R.Hart ${ }^{\mathrm{c}}$, K.A.Farley ${ }^{\mathrm{d}}$, \\ J.S.Blusztajn ${ }^{\mathrm{c}}$, J.D.Woodhead ${ }^{\mathrm{e}}$ \\ ${ }^{a}$ Department of Earth Science, University of California, Santa Barbara, USA \\ (garapicg@newpaltz.edu) \\ ${ }^{b}$ Department of Terrestrial Magnetism, Carnegie Institution of Washington, Washington, \\ DC 20015, USA \\ ${ }^{c}$ Department of Marine Geology and Geophysics, Woods Hole Oceanographic Institution, \\ 266 Woods Hole Road, Woods Hole, Massachusetts 02543, USA \\ ${ }^{d}$ Geological and Planetary Sciences Division, California Institute of Technology, \\ Pasadena, California 91125, USA \\ ${ }^{e}$ School of Earth Sciences, The University of Melbourne, Victoria 3010, Australia
}

\begin{abstract}
We present new He-Sr-Nd-Pb-Os isotopic compositions and major and traceelement concentrations for ten subaerially-erupted lavas and one seamount lava associated with the Pitcairn hotspot. The most geochemically-enriched lavas at the Pitcairn hotspot have signatures that are consistent with recycled sediments derived from upper continental crust. Pitcairn lavas have elevated Ti, which also supports the presence of a mafic protolith in the Pitcairn mantle. A subset of Pitcairn seamount samples, including the seamount sample presented here, are tholeiitic. Tholeitic lavas are uncommon at ocean hotspots located far from mid-ocean ridges. Like tholeiites erupted at Hawaii, the presence of tholeiites in the Pitcairn magmatic suite can be
\end{abstract}

\footnotetext{
${ }^{1}$ Now at Geology department, SUNY New Paltz, New Paltz, NY, USA
} 
explained by melting a silica-saturated recycled mafic component in the Pitcairn mantle source. We also present the highest ${ }^{3} \mathrm{He} /{ }^{4} \mathrm{He}$ ratio (12.6 Ra, ratio to atmosphere) from the Pitcairn hotspot. This sample anchors the high ${ }^{206} \mathrm{~Pb} /{ }^{204} \mathrm{~Pb}$ portion of the Pitcairn array and provides evidence for a plume component in the Pitcairn mantle. In contrast, Pitcairn lavas that have the lowest ${ }^{206} \mathrm{~Pb} /{ }^{204} \mathrm{~Pb}$ are the most geochemically enriched, and have the highest ${ }^{87} \mathrm{Sr} /{ }^{86} \mathrm{Sr}$ and lowest ${ }^{143} \mathrm{Nd} /{ }^{144} \mathrm{Nd}$ in the Pitcairn suite; these EM-1 end-member lavas have MORB-like ${ }^{3} \mathrm{He} /{ }^{4} \mathrm{He}(\sim 8 \mathrm{Ra}$, ratio to atmosphere). Recycled oceanic crust and sediment suggested to be in the Pitcairn EM-1 mantle are expected to have low ${ }^{3} \mathrm{He} /{ }^{4} \mathrm{He}(<0.1 \mathrm{Ra})$. Therefore, the higher, MORB-like ${ }^{3} \mathrm{He} /{ }^{4} \mathrm{He}$ in Pitcairn EM-1 lavas is paradoxical, but might be explained by diffusive exchange of helium, but not the heavy radiogenic isotopes, with the ambient mantle over billion-year timescales.

Keywords: Pitcairn, EM-1, sediment recycling, pelagic clays, crustal recycling, tholeiite, FOZO, ${ }^{3} \mathrm{He} /{ }^{4} \mathrm{He}$, ocean island basalt (OIB), hotspot, Hawaii

\section{Introduction}

2 Geochemical analyses of ocean island basalts (OIB) erupted at hotspots 3 reveal that the Earth's mantle is compositionally heterogeneous (e.g., Gast 4 et al., 1964; Zindler and Hart, 1986; Hofmann, 1997, 2003; White, 2010; 5 Stracke, 2012). Compilations of radiogenic isotopic measurements made on 6 OIB show that several distinct isotopic compositions emerge from the global dataset (Zindler and Hart, 1986), including EM-1 (enriched mantle 1), which 8 is characterized by the unradiogenic ${ }^{206} \mathrm{~Pb} /{ }^{204} \mathrm{~Pb}$ ratios with moderately high 
${ }^{208} \mathrm{~Pb} /{ }^{204} \mathrm{~Pb}$ and ${ }^{87} \mathrm{Sr} /{ }^{86} \mathrm{Sr}$, EM-2 (enriched mantle 2) which is characterized by intermediate ${ }^{206} \mathrm{~Pb} /{ }^{204} \mathrm{~Pb}$ ratios and highly radiogenic ${ }^{87} \mathrm{Sr} /{ }^{86} \mathrm{Sr}$, and HIMU (high $\mu$, or high ${ }^{238} \mathrm{U} /{ }^{204} \mathrm{~Pb}$ ), which is characterized by the the most radiogenic $\mathrm{Pb}$ isotopic compositions in the oceanic mantle. Geochemicallydepleted compositions are also sampled by hotspots, and the origin of the depleted component in plumes is not well understood and may host elevated (primordial) ${ }^{3} \mathrm{He} /{ }^{4} \mathrm{He}$ ratios (Hart et al., 1992; Farley et al., 1992; Hanan and Graham, 1996). Mixing of the EM-1, EM-2 and HIMU end-members with the depleted composition is thought to generate much of the diversity in OIB.

While the field of mantle geochemistry has advanced to a state of careful description and classification of the various mantle species, and their possible mixing relationships, the origin of these species still remains poorly understood. Models explaining the sources of the mantle end-members often call for subduction injection of surface materials, including continental crust, oceanic crust, and sediments into the mantle over geologic time (Hofmann and White, 1982). Following mixing with ambient mantle, the subducted protoliths are sampled by regions of upwelling mantle, called plumes, and melted beneath hotspots. Alternative hypotheses for the origin of the various end-members include delamination of subcontinental lithosphere (McKenzie and O'Nions, 1983; Mahoney et al., 1991), $\mathrm{CO}_{2}$-flux induced melting of pristine mantle domain in the lower mantle (Collerson et al., 2010), and more exotic metasomatic processes, where fluids in the mantle impart enriched geochemical signatures on specific domains of the mantle (e.g., Menzies and Murthy, 1980; Menzies, 1983; Niu and O'Hara, 2003; Workman et al., 2004; 
Geldmacher et al., 2008; Salters and Sachi-Kocher, 2010; Pilet et al., 2011).

However, a consensus is emerging for the origin of EM-2 as recycled marine sediment (Workman et al., 2008) with a terrigenous origin (Jackson et al., 2007a). Similarly, the long-standing hypothesis that HIMU represents recycled oceanic crust (Hofmann and White, 1982; Zindler et al., 1982; Eiler et al., 1997) is gaining strength (Hanyu et al., 2011; Kawabata et al., 2011; Cabral et al., 2013; Hanyu et al., 2014).

Among all mantle end-members, no consensus has emerged for the origin of EM-1 (e.g., Hofmann, 1997; Hart, 2011) and yet numerous mechanisms have been proposed (e.g., Woodhead and McCulloch, 1989; Weaver, 1991; Mahoney et al., 1991; Chauvel et al., 1992; Woodhead and Devey, 1993; Eiler et al., 1995; Rehkämper and Hofmann, 1997; Lassiter and Hauri, 1998; Blichert-Toft et al., 1999a; Gasperini et al., 2000; Tatsumi, 2000; Eisele et al., 2002; Escrig et al., 2004; Hanan et al., 2004; Honda and Woodhead, 2005; Brandenburg et al., 2008; Geldmacher et al., 2008; Salters and Sachi-Kocher, 2010; Collerson et al., 2010; Willbold and Stracke, 2010). Here, armed with a new geochemical dataset from the Pitcairn hotspot, we argue for the presence of recycled sediment in the Pitcairn EM-1 mantle (e.g., Eisele et al., 2002; Honda and Woodhead, 2005), and we suggest that Pitcairn lavas also sample recycled oceanic crust. We also report new helium data on Pitcairn lavas, including the highest ${ }^{3} \mathrm{He} /{ }^{4} \mathrm{He}$ ratio from Pitcairn, and the new data provide insights into the evolution of the poorly-understood high ${ }^{3} \mathrm{He} /{ }^{4} \mathrm{He}$ mantle and EM-1 mantle reservoirs. 


\section{Methods}

The ten subaerial lavas from Pitcairn island reported here were collected by Ken Farley during the 1989 Helios Expedition. We do not report ages for the samples in this study, but subaerial lavas from Pitcairn have ages between 0.4 and 1.0 Ma (Duncan et al., 1974). Figure 1 shows locations for the subaerial samples presented in this study. Based on comparison with the geological formations as mapped by Carter (1967), the samples in this study were collected from the Tedside (Pit-1, Pit-3, Pit-4, Pit-7, Pit-8) and Pulawana volcanic formations (Pit-6, Pit-16, Pit-11, Pit-12, Pit-13). Samples Pit-6, 12, 13 and 16 were collected in place from outcrops. Samples Pit-1, 3, 4a, 7, 8 and 11 were collected as cobbles on the wave cut terrace; it is very likely that cobbles on the terrace derive from the overlying cliff as there are no rivers to transport cobbles and longshore transport is not plausible.

We also report new geochemical data on a single submarine sample, 65DS4, dredged between 1503 and 1276 m water depth on Adams Seamount (25021'26", $\left.125^{\circ} 18^{\prime} 59^{\prime \prime}\right)$, located $\sim 90 \mathrm{~km}$ ESE of Pitcairn. This sample was recovered aboard the FS Sonne on December 1989 on the 65th cruise of this vessel (Stoffers et al., 1990; Woodhead and Devey, 1993). The seafloor extending $\sim 90 \mathrm{~km}$ ESE of Pitcairn Island is populated by a submarine volcanic field hosting approximately 90 volcanic cones and seamounts, including Adams Seamount (Hekinian et al., 2003), the largest seamount in this volcanic field (Woodhead and Devey, 1993; Hekinian et al., 2003). Several of these volcanic features exhibit evidence of being active, and submarine dredges returned samples with fresh volcanic rocks and glass; there was little evidence for sediment cover (Stoffers et al., 1990). Seafloor backscatter im- 
ages revealed that several of the volcanic edifices are highly reflective, further supporting a young age for these seamounts, and substantiating the hypothesis that that these seamounts (including Adams Seamount) mark the active portion of the Pitcairn hotspots (Woodhead and McCulloch, 1989; Stoffers et al., 1990; Hekinian et al., 2003). K/Ar age determinations of lavas recovered from Adams Seamount range from 2 to 7 kyr (Guillou et al., 1997) and volcanic rocks recovered from this seamount exhibit evidence of only slight alteration (Hekinian et al., 2003). Additionally, geochemical data obtained on seven dredges of Adams Seamount, including new data presented here on sample 65DS-4, indicate that this seamount has a Pitcairn hotspot pedigree (Woodhead and Devey, 1993). Given this significant body of evidence, we adopt the finding that Adams Seamount marks the active end of the Pitcairn hotspot.

Cut rock slabs were crushed in plastic bags to avoid contamination with metal from the hammer, and the freshest chips were separated and powdered in agate. With the exception of sample 65DS-4, major elements and a subset of trace elements were measured on powders by XRF in the laboratory of Michael Rhodes at the University of Massachusetts Amherst, and the methods and associated errors are reported in Rhodes (1988). The remaining trace elements were measured by ICP-MS at the Geoanalytical Lab at Washington State University (WSU) (Knaack et al., 1994). For sample 65DS-4, major and trace elements were measured at WSU by XRF and ICP-MS (analytical methods and errors are reported in Johnson et al., 1999; Knaack et al., 1994). At WSU, precision for the analyses of $\mathrm{SiO}_{2}, \mathrm{Al}_{2} \mathrm{O}_{3}, \mathrm{TiO}_{2}$ and $\mathrm{P}_{2} \mathrm{O}_{5}$ in basalts is $0.110 .33 \%(1 \sigma)$ of the amount present, and $0.38 \quad 0.71 \%(1 \sigma)$ 
of the amount present for $\mathrm{FeO}, \mathrm{MgO}, \mathrm{CaO}, \mathrm{Na}_{2} \mathrm{O}, \mathrm{MnO}$ and $\mathrm{K}_{2} \mathrm{O}$ (Johnson et al., 1999). Trace element analyses by ICP-MS at WSU have a precision of $0.773 .2 \%(1 \sigma)$ for all elements except for Th $(9.5 \%)$ and $\mathrm{U}(9.3 \%)$ (Knaack et al., 1994). Sample 65DS-4 is an olivine cumulate, and we present XRF major element data on the whole rock and on (olivine-free) matrix separated from the sample.

For the subaerial lavas, chemical separation protocols and $\mathrm{Sr}$ and $\mathrm{Nd}$ isotopic measurements were made at the Woods Hole Oceanographic Institution and follow the same protocols outlined in Hauri and Hart (1993); Sr and Nd isotopic data have never been reported for these samples. Sr-isotopic compositions were fractionation corrected relative to ${ }^{86} \mathrm{Sr} /{ }^{88} \mathrm{Sr}=0.1194$, and ${ }^{87} \mathrm{Sr} /{ }^{86} \mathrm{Sr}$ ratios were adjusted to an SRM987 value of 0.710240 . The external precision for the ${ }^{87} \mathrm{Sr} /{ }^{86} \mathrm{Sr}$ ratio is estimated to be $45 \mathrm{ppm}$, and is based on repeat analyses of the SRM987 Sr standard. Nd-isotopic compositions were fractionation corrected relative to a ${ }^{146} \mathrm{Nd} /{ }^{150} \mathrm{Nd}$ value of 0.7219 . The ${ }^{143} \mathrm{Nd} /{ }^{144} \mathrm{Nd}$ ratios were adjusted to a value of 0.511847 for the La Jolla $\mathrm{Nd}$ standard. The external precision on the ${ }^{143} \mathrm{Nd} /{ }^{144} \mathrm{Nd}$ is estimated to be 40 $\mathrm{ppm}$, and is based on repeat measurements of the La Jolla Nd standard. $\mathrm{Pb}$ isotopic data for the subaerial samples were previously reported for all samples in Eiler et al. (1995), except for sample Pit-6, which is reported here; analytical procedures and fractionation correction are the same as outlined in Hauri and Hart (1993), and Pb-isotopic ratios for sample Pit-6 were adjusted to SRM981 values from (Todt et al., 1996) to be consistent with the data reported in Eiler et al. (1995). Sr, Nd and Pb chemical separation protocols and isotopic analyses for the submarine lava, 65DS-4, follow those outlined 
in Hart and Blusztajn (2006); Sr, Nd and Pb isotopic measurements were made on the Neptune multi-collector ICP-MS at WHOI. After adjusting to 0.710240 and 0.511847 for SRM987 and La Jolla Nd standards, respectively, the external precision is estimated to be between 15-25 ppm. Pb-isotopic measurements were adjusted to the SRM 981 values reported in (Todt et al., 1996), and external reproducibility is estimated to be better than $120 \mathrm{ppm}$ for the ${ }^{206} \mathrm{~Pb} /{ }^{204} \mathrm{~Pb},{ }^{207} \mathrm{~Pb} /{ }^{204} \mathrm{~Pb}$ and ${ }^{208} \mathrm{~Pb} /{ }^{204} \mathrm{~Pb}$ ratios.

Osmium isotopic analyses were performed on 315 to $820 \mathrm{mg}$ of olivine separated from six Pitcairn samples. Samples were dissolved by $\mathrm{HF}-\mathrm{HCl}$ dissolution, subjected to a gentle dry down at $<100^{\circ} \mathrm{C}$, then loaded in Carius Tubes as described in Shirey and Walker (1995); chemical separation of Os is as described in Shirey and Walker (1995). The isotopic analyses were made at DTM by negative thermal ionization mass spectrometry (N-TIMS) (Hauri and Kurz, 1997). In-run precision was better than 0.1\% (2 $\sigma$ standard error of the mean) on the ${ }^{187} \mathrm{Os} /{ }^{188} \mathrm{Os}$ ratio for all runs. Total procedural blanks were $<5$ pg Os and were within analytical errors. Analyses of the DTM osmium standard yielded an average ${ }^{187} \mathrm{Os} /{ }^{188}$ Os of $0.11378 \pm 10(2 \sigma$, $\mathrm{n}=5$ ). Helium isotopic measurements were made on 0.9 to $3.8 \mathrm{~g}$ of olivine phenocrysts by crushing in vacuo and follow the methods outlined in Farley et al. (1993). Uncertainties on the ${ }^{3} \mathrm{He} /{ }^{4} \mathrm{He}$ ratios are estimated to be \pm 0.5 Ra; the estimated uncertainties account for both blank correction and uncertainty in standards of similar size to samples. The sample with the highest ${ }^{3} \mathrm{He} /{ }^{4} \mathrm{He}$, Pit-16, was measured twice on more than $4 \mathrm{~g}$ of olivine, on coarse (11.8 Ra) and fine (13.3 Ra) olivine fractions (the average value of the two measurements, $12.6 \mathrm{Ra}$, is used hereafter), to verify the elevated ${ }^{3} \mathrm{He} /{ }^{4} \mathrm{He}$ 
ratio; the raw ratios were 10.5 and $11.5 \mathrm{Ra}$, so even without blank correction the sample is unusual. This sample was collected on a sea-cliff, where erosion enhanced by continuous wave action precludes long-term exposure at the surface, which enables us to exclude a cosmogenic helium origin for the elevated isotopic ratio in this sample.

The new isotopic data are presented in Table 1, together with previously published data on these samples. Additionally, in Table 2 we report major element abundances for olivine phenocrysts from submarine sample 65DS-4; these data complement previously-published olivine compositional data on subaerially-erupted lavas from the hotspot (Eiler et al., 1995). Microprobe analyses were made on Cameca SX-100 at UC Santa Barbara with the following operating conditions: $15 \mathrm{kV}$ accelerating voltage, $15 \mathrm{nA}$ beam current and $1 \mu \mathrm{m}$ beam diameter.

\section{Data}

All of the samples in this study are porphyritic in texture. According to a TAS classification (Figure 2), subaerial Pitcairn lavas are predominantly alkalic and span the whole suite of compositions from alkaline basalts to trachy-andesites. Most of the submarine lavas are also alkalic, but a limited number of seamount samples cross the alkali-tholeiite division of Macdonald and Katsura (1964) and are tholeiitic, as was noted by Hekinian et al. (2003). The new seamount sample, 65DS-4, is clearly tholeitic, based on its wholerock and matrix major element composition.

Figure 3 shows variation diagrams of $\mathrm{MgO}$ versus major element oxides. Olivine fractionation dominates the major element variations for bulk rock 
compositions $>8-10$ wt. $\% \mathrm{MgO}$. At $\mathrm{MgO}<8-10$ wt.\%, clinopyroxene fractionation is apparent from reduced $\mathrm{CaO} / \mathrm{Al}_{2} \mathrm{O}_{3}$ ratios. Fractionation of Feand Ti-rich phases is evident in lavas with $\mathrm{MgO}<5$ wt.\%.

The panels in Figure 4 display isotopic compositions for the new Pitcairn hotspot dataset compared to previously published Pitcairn data and other OIB. Separate fields are designated for Samoa, which represents the extreme EM-2 end-member, and for Hawaii. A separate distinction within the Hawaiian field is made for Koolau lavas because these lavas host an enriched end-member that has an EM-1 pedigree. However, Pitcairn and Hawaiian Koolau lavas have distinct EM-1 flavors. In both, ${ }^{208} \mathrm{~Pb} /{ }^{204} \mathrm{~Pb}$ versus ${ }^{206} \mathrm{~Pb} /{ }^{204} \mathrm{~Pb}$ and ${ }^{207} \mathrm{~Pb} /{ }^{204} \mathrm{~Pb}$ versus ${ }^{206} \mathrm{~Pb} /{ }^{204} \mathrm{~Pb}$ diagrams, Pitcairn and Hawaii form two separate fields, and highlight the difference in the EM1 composition between the two hotspots. However, in ${ }^{143} \mathrm{Nd} /{ }^{144} \mathrm{Nd}$ versus ${ }^{87} \mathrm{Sr} /{ }^{86} \mathrm{Sr}$ isotopic space, Pitcairn overlaps with Hawaiian Koolau lavas, highlighting the complementary EM-1 signatures present at both hotspots, in spite of their different $\mathrm{Pb}$-isotopic compositions. The plot of ${ }^{208} \mathrm{~Pb} /{ }^{204} \mathrm{~Pb}$ versus ${ }^{206} \mathrm{~Pb} /{ }^{204} \mathrm{~Pb}$ reveals the presence of a third component in Pitcairn lavas (located at the lowest vertex of the triangle outlining the Pitcairn dataset in $\mathrm{Pb}$-isotope space in Figure 4), and this component is characterized by lower ${ }^{208} \mathrm{~Pb} /{ }^{204} \mathrm{~Pb}$ at a given ${ }^{206} \mathrm{~Pb} /{ }^{204} \mathrm{~Pb}$. Curiously, this third component is only visible in ${ }^{208} \mathrm{~Pb} /{ }^{204} \mathrm{~Pb}$ versus ${ }^{206} \mathrm{~Pb} /{ }^{204} \mathrm{~Pb}$ isotope space, and is not evident in other isotope projections. Sample 65DS-4 defines the end-member composition for this new component, and it plots closer to Hawaiian Koolau lavas in $\mathrm{Pb}$-isotopic space than any previously examined Pitcairn lava. We emphasize that a subset of prior analyses of lavas from the Pitcairn hotspot 
have $\mathrm{Sr}, \mathrm{Nd}$ and $\mathrm{Pb}$ isotopic compositions that are similar to $65 \mathrm{DS}-4$, but this sample slightly expands the field of the Pitcairn hotspot in ${ }^{208} \mathrm{~Pb} /{ }^{204} \mathrm{~Pb}$ versus ${ }^{206} \mathrm{~Pb} /{ }^{204} \mathrm{~Pb}$ isotopic space.

Figure 5 shows ${ }^{3} \mathrm{He} /{ }^{4} \mathrm{He}$ ratios in olivine in subaerial samples (reported here for the first time) and seamount glasses (reported in Honda and Woodhead, 2005), plotted against ${ }^{206} \mathrm{~Pb} /{ }^{204} \mathrm{~Pb}$. At a given ${ }^{206} \mathrm{~Pb} /{ }^{204} \mathrm{~Pb}$ ratio, the ${ }^{3} \mathrm{He} /{ }^{4} \mathrm{He}$ of the olivines is bracketed by the ${ }^{3} \mathrm{He} /{ }^{4} \mathrm{He}$ of the glass dataset; only the Pit-16 olivine ${ }^{3} \mathrm{He} /{ }^{4} \mathrm{He}$ measurement is higher than any of the ${ }^{3} \mathrm{He} /{ }^{4} \mathrm{He}$ measurements on glasses. The ${ }^{3} \mathrm{He} /{ }^{4} \mathrm{He}$ of the Pitcairn olivines presented here show no evidence for reduced ${ }^{3} \mathrm{He} /{ }^{4} \mathrm{He}$ by radiogenic ingrowth of $4 \mathrm{He}$. Figure 5 also shows a possible relationship between ${ }^{206} \mathrm{~Pb} /{ }^{204} \mathrm{~Pb}$ and ${ }^{3} \mathrm{He} /{ }^{4} \mathrm{He}$, where the highest ${ }^{3} \mathrm{He} /{ }^{4} \mathrm{He}$ ratio is found in the sample with the highest ${ }^{206} \mathrm{~Pb} /{ }^{204} \mathrm{~Pb}$. In comparison, the two lavas with the lowest ${ }^{206} \mathrm{~Pb} /{ }^{204} \mathrm{~Pb}$ have the lowest ${ }^{3} \mathrm{He} /{ }^{4} \mathrm{He}$ ratios, $7.7 \mathrm{Ra}$ (measured in a glass) and 8.0 Ra (measured in olivine), indicating that EM-1 lavas at Pitcairn have MORB-like ${ }^{3} \mathrm{He} /{ }^{4} \mathrm{He}$.

Figure 6 shows ${ }^{187} \mathrm{Os} /{ }^{188} \mathrm{Os}$ ratios and Os concentrations measured on olivines from samples from this study compared to the whole rock measurements of Pitcairn lavas from previous studies (Reisberg et al., 1993; Eisele et al., 2002). ${ }^{187} \mathrm{Os} /{ }^{188} \mathrm{Os}$ ratios in olivines from this study range from 0.1342 to 0.1432 , which falls within the range previously identified in whole-rock measurements of the most Os-rich Pitcairn samples (0.131 to 0.148 for samples with Os $>50 \mathrm{pg} / \mathrm{g}$ ) (see Figure 2b in Eisele et al., 2002). As observed by Eisele et al. (2002), there are no clear relationships between Os isotopic ratios and the other radiogenic isotopic compositions presented in this study. Rhenium was not measured on the olivines, so an age-correction cannot be 
performed. However, recent studies on magmatic olivines from Samoa (Jackson and Shirey, 2011), Iceland (Debaille et al., 2009) and the Cook Islands (Hanyu et al., 2011) indicate that Re/Os ratios in magmatic olivines are low, and the subaerial lavas from Pitcairn are young, so any age-correction to the ${ }^{187} \mathrm{Os} /{ }^{188} \mathrm{Os}$ ratio of the olivine will be small.

Figure 7 displays $\mathrm{SiO}_{2}$ data plotted against ${ }^{206} \mathrm{~Pb} /{ }^{204} \mathrm{~Pb}$ for Pitcairn, together with the global OIB dataset from Jackson and Dasgupta (2008) and a Hawaiian dataset from Jackson et al. (2012). With the exception of the matrix analysis from sample 65DS-4, only Pitcairn samples with $\mathrm{MgO}>9 \%$ are plotted, and all lavas were corrected for olivine fractionation. The data show that, with Hawaii, Pitcairn lavas anchor the low ${ }^{206} \mathrm{~Pb} /{ }^{204} \mathrm{~Pb}, \mathrm{SiO}_{2}$-rich portion of the global OIB array.

\section{Discussion}

\subsection{Recycled sediment in the source of Pitcairn EM-1 lavas}

Previous work on the EM-1 signature hosted in Pitcairn lavas (Woodhead and McCulloch, 1989; Woodhead and Devey, 1993; Eisele et al., 2002; Honda and Woodhead, 2005) argued that the data are consistent with sediment addition to the mantle source: EM-1 Pitcairn lavas have high ${ }^{87} \mathrm{Sr} /{ }^{86} \mathrm{Sr}$ and ${ }^{187} \mathrm{Os} /{ }^{188} \mathrm{Os}$, low ${ }^{143} \mathrm{Nd} /{ }^{144} \mathrm{Nd}$, and Nb-depletion $\left(\mathrm{Nb} / \mathrm{Nb}^{*}<1\right)$ (e.g. Eisele et al., 2002; Honda and Woodhead, 2005). Additionally, EM-1 lavas from Pitcairn tend to have low Ce/Pb ratios (e.g. Honda and Woodhead, 2005), which is a characteristic of marine sediments (e.g. Plank and Langmuir, 1998).

More recently, Willbold and Stracke (2010) argued for recycling of lower 
continental crust to generate EM-1 signatures in oceanic lavas, which follows prior work suggesting a similar origin for the EM-1 mantle (Tatsumi, 2000; Escrig et al., 2004; Hanan et al., 2004; Willbold and Stracke, 2010). Willbold and Stracke (2010) relied on $\mathrm{Eu} / \mathrm{Eu}^{*}$ to distinguish between upper and lower continental crust in the mantle source of Pitcairn lavas: Upper continental crust has negative $\mathrm{Eu} / \mathrm{Eu}^{*}$, and lower continental crust has positive $\mathrm{Eu} / \mathrm{Eu}^{*}$. Intriguingly, the Pitcairn lavas in Willbold and Stracke (2010)(refer to Figure 4 of said reference) show no clear Eu-anomaly, and most of the Pitcairn lavas in Willbold and Stracke (2010) actually have Eu/Eu* values slightly less than one, which is consistent with the addition of recycled upper continental crust. While $\mathrm{Eu} / \mathrm{Eu}^{*}$ may be useful for distinguishing a lower continental crust component in several EM-1 hotspots globally, it may not support a lower continental crust component at the Pitcairn hotspot, and permits a model whereby upper continental crust and derivative sediments exist in the Pitcairn mantle.

Sediments derived from upper continental crust have the necessary geochemical ingredients for generating an EM-1 mantle source sampled by Pitcairn lavas. However, upper continental crust and derivative sediments are highly heterogeneous (Plank and Langmuir, 1998; Rudnick and Gao, 2003). To better characterize the type of the crustal material that contributes to the EM-1 source, we point out two distinctive geochemical feature of EM-1 as sampled by Pitcairn lavas: 1. Pitcairn lavas exhibit a range of highly unradiogenic ${ }^{206} \mathrm{~Pb} /{ }^{204} \mathrm{~Pb}$ ratios associated with relatively high ${ }^{208} \mathrm{~Pb} /{ }^{204} \mathrm{~Pb}$, and 2. The most geochemically-enriched Pitcairn lava with Hf-isotopic data departs from the global array formed by ${ }^{143} \mathrm{Nd} /{ }^{144} \mathrm{Nd}$ and ${ }^{176} \mathrm{Hf} /{ }^{177} \mathrm{Hf}$ and 
trends toward a component with high ${ }^{176} \mathrm{Hf} /{ }^{177} \mathrm{Hf}$ at a given ${ }^{143} \mathrm{Nd} /{ }^{144} \mathrm{Nd}$ (Eisele et al., 2002). The former geochemical characteristic indicates that the protolith contributing to the enriched mantle source beneath Pitcairn must also have high Th/U (Eisele et al., 2002). Sediments can have high Th/U, and pelagic clays have among the highest $\mathrm{Th} / \mathrm{U}$, as they are the weathering products of mature upper continental crust (where U has been preferentially mobilized relative to Th over time) (Plank and Langmuir, 1998). Eisele et al. (2002) demonstrated that the $\mathrm{Th} / \mathrm{U}$ ratio in pelagic sediments will generate $\mathrm{Pb}$-isotopic systematics appropriate for Pitcairn hotspot lavas over time. Pelagic clays also satisfy the ${ }^{176} \mathrm{Hf} /{ }^{177} \mathrm{Hf}$ systematics in Pitcairn lavas since they do not contain detrital zircon, a Hf-rich phase. The presence of detrital zircon in a sediment would yield lower $\mathrm{Lu} / \mathrm{Hf}$ ratios at a given $\mathrm{Sm} / \mathrm{Nd}$ ratio, and the departure of Pitcairn lavas from the mantle array suggests the presence of a zircon-poor pelagic sediment. Therefore, among possible subducted protoliths in the EM-1 mantle, pelagic sediments have the combination of high $\mathrm{Th} / \mathrm{U}$ and high $\mathrm{Lu} / \mathrm{Hf}$ required to generate the $\mathrm{Nd}$, Hf and $\mathrm{Pb}$ isotopic compositions in Pitcairn EM-1 lavas. Therefore, based on the geochemical characteristics inferred for the Pitcairn EM-1 mantle source, incorporation of a pelagic sedimentary protolith into the mantle sourced by Pitcairn EM-1 lavas remains a plausible model for the origin of this mantle end-member (Woodhead and McCulloch, 1989; Woodhead and Devey, 1993; Eisele et al., 2002; Honda and Woodhead, 2005).

\subsection{The presence of subducted oceanic crust in the EM-1 Pitcairn mantle}

Eisele et al. (2002) modeled the mantle source of the EM-1 Pitcairn mantle and found that, in addition to supporting a role for recycled pelagic 
sediment in the EM-1 mantle, the model results permit the presence of a mafic component in the EM-1 Pitcairn mantle. High concentrations of $\mathrm{TiO}_{2}$ in OIB lavas, including lavas from the Pitcairn suite, have also been used to argue for a recycled mafic component in their mantle sources (Prytulak and Elliot, 2007). This is because melting of a primitive or depleted mantle peridotite cannot generate the elevated $\mathrm{TiO}_{2}$ observed in primitive OIB lavas from many hotspots, even at very low degrees of melting. We emphasize that elevated $\mathrm{Ti}$ concentrations do not translate to particularly striking $\mathrm{Ti}$, $\mathrm{Ta}$ and $\mathrm{Nb}$ (TITAN) anomalies (Jackson et al., 2008) in the new dataset; this is because the concentrations of these elements are generally complemented by higher concentrations of elements of similar incompatibility. While the presence of a mafic component in the Pitcairn mantle is indicated from elevated $\mathrm{TiO}_{2}$ in Pitcairn lavas, it is important to evaluate the nature of this mafic component.

With the exception of the tholeiitic seamount samples from the Pitcairn hotspot (including sample 65DS-4), most Pitcairn lavas are alkalic and silica undersaturated, which suggests the mafic component in the mantle source is silica-undersaturated (i.e., a silica-deficient pyroxenite; Herzberg, 2011). This silica-undersaturated mafic component may be responsible for elevating the $\mathrm{TiO}_{2}$ in alkalic Pitcairn lavas.

The less common tholeiitic samples from the Pitcairn hotspot offer important clues to silica-saturated recycled mafic compositions in the Pitcairn mantle. Together with Koolau lavas from Hawaii (e.g., Hauri, 1996), lavas from the Pitcairn hotspot, in particular the submarine Pitcairn seamount lavas (e.g., Woodhead and Devey, 1993; Eisele et al., 2002; Hekinian et al., 
2003), anchor the $\mathrm{SiO}_{2}$-rich portion of the global OIB array (Figure 7, Jackson and Dasgupta (2008). The similarity in $\mathrm{SiO}_{2}$ contents in both the Pitcairn seamount lavas (including sample 65-DS4) and Koolau lavas may suggest that mantle sources at both EM-1 localities may generate $\mathrm{SiO}_{2}$-rich lavas. The observation of tholeiitic samples at the Pitcairn hotspot is important and can give important clues to the nature of the EM-1 mantle, as oceanic hotspot lavas erupted far from mid-ocean ridges (i.e., excluding nearridge hotspots like Iceland and Galapagos) are predominantly alkalic. Among hotspots erupted far from mid-ocean ridges, excluding Hawaii, tholeiitic lavas are uncommon (¡10\%). Of 14 such hotspots tabulated by Jackson and Dasgupta (2008), all plot, on average, in the alkali basalt field of Macdonald and Katsura (1964).

The new tholeiitic Pitcairn seamount sample, 65DS-4, not only has the highest olivine-corrected $\mathrm{SiO}_{2}$ abundance in the Pitcairn dataset, but it also extends the Pitcairn field closer to the Koolau EM-1 field in Pb-isotopic space than any previously examined Pitcairn lava (Figure 4). The geochemical affinities suggest there may be broad similarities, including geochemicallyenriched $\mathrm{Sr}$ and $\mathrm{Nd}$ isotopic compositions and elevated $\mathrm{SiO}_{2}$, in the mantle sources sampled by the low ${ }^{208} \mathrm{~Pb} /{ }^{204} \mathrm{~Pb}$ component in Pitcairn (which is exhibited in purest form by 65DS-4; Figure 4) and the EM-1 component in Koolau lavas. The origin of the $\mathrm{SiO}_{2}$-rich nature of Koolau lavas from Hawaii is argued to be the result of eclogite melting in the Hawaiian mantle plume (Sobolev et al., 2005; Hauri, 1996; Herzberg, 2011), where the eclogite is suggested to be recycled oceanic crust that preserved low $\mathrm{U} / \mathrm{Pb}$ ratios through the subduction zone and generated relatively low time-integrated ${ }^{206} \mathrm{~Pb} /{ }^{204} \mathrm{~Pb}$ 
(Jackson and Dasgupta, 2008; Jackson et al., 2012). Hauri (1996) showed that existing peridotite melting experiments at pressures $>2 \mathrm{GPa}$ (i.e., pressures that are slightly lower than the pressure at the base of mature oceanic lithosphere beneath Pitcairn and Hawaii) cannot generate the major element compositions observed in Koolau lavas, and more recent compilations of experimental data support this observation (see discussion in Jackson et al., 2012). Hauri (1996) Hauri (1996) also showed that elevated FeO at a given $\mathrm{SiO}_{2}$ in Koolau lavas is a result of eclogite melting. Given existing experiment constraints, the high $\mathrm{FeO}$ and $\mathrm{SiO}_{2}$-rich tholeiites from Hawaii are best explained by melting a silica-saturated, mafic protolith in the mantle source (Hauri, 1996; Jackson et al., 2012). Sample 65DS-4 and a subset of Pitcairn seamount samples plot within or close to the Hawaiian Koolau field in a plot of $\mathrm{SiO}_{2}$ vs. $\mathrm{FeO}$ (Figure 8); sample 65DS-4 plots in the field for Mauna Loa lavas, which also host elevated $\mathrm{FeO}$ at a given $\mathrm{SiO}_{2}$ abundance, and like Koolau lavas, are argued to be melts of an eclogite-bearing mantle source (Hauri, 1996; Lassiter and Hauri, 1998; Blichert-Toft et al., 1999a; Huang and Frey, 2005; Sobolev et al., 2005; Herzberg, 2006; Jackson et al., 2012). Therefore, we suggest that a subset of EM-1 Pitcairn lavas, which have $\mathrm{SiO}_{2}$ abundances that anchor the high- $\mathrm{SiO}_{2}$ portion of the data arrays in Figures 7 and 8, sample a mantle source that is lithologically similar to the mantle source of high- $\mathrm{SiO}_{2}$ Hawaiian lavas (Mauna Loa and Koolau). 


\subsection{Helium isotopic constraints on the mantle source beneath Pitcairn}

4.3.1. Origin of the depleted high ${ }^{3} \mathrm{He} /{ }^{4} \mathrm{He}$ component hosted in Pitcairn lavas: Entrained depleted upper mantle or a depleted plume (FOZO?) component?

The new data provide a window into the high ${ }^{3} \mathrm{He} /{ }^{4} \mathrm{He}$ component in the Pitcairn suite. The Pitcairn lava (Pit-16) with the highest ${ }^{3} \mathrm{He} /{ }^{4} \mathrm{He}(12.6$ Ra, ratio to atmosphere) is also the sample with the highest ${ }^{206} \mathrm{~Pb} /{ }^{204} \mathrm{~Pb}$ that has been examined for helium isotopes (Figure 5). Additionally, with increasing ${ }^{206} \mathrm{~Pb} /{ }^{204} \mathrm{~Pb}$, Pitcairn lavas exhibit increasingly depleted geochemical signatures, including higher ${ }^{143} \mathrm{Nd} /{ }^{144} \mathrm{Nd}$ and lower ${ }^{87} \mathrm{Sr} /{ }^{86} \mathrm{Sr}$ (Figure 4). While the high ${ }^{3} \mathrm{He} /{ }^{4} \mathrm{He}$ Pitcairn sample, Pit-16, is not itself geochemicallydepleted $\left({ }^{143} \mathrm{Nd} /{ }^{144} \mathrm{Nd}\right.$ is $0.512590,{ }^{87} \mathrm{Sr} /{ }^{86} \mathrm{Sr}$ is 0.704687$)$, it plots in a region of isotopic space that is closer to the most depleted Pitcairn component (but farther from the EM-1 domain) than other lavas from Pitcairn that have been characterized for helium isotopes (Figure 4). Therefore, going in the direction of the depleted Pitcairn component in isotopic space, ${ }^{3} \mathrm{He} /{ }^{4} \mathrm{He}$ appears to increase. Since MORB lavas tend to have ${ }^{3} \mathrm{He} /{ }^{4} \mathrm{He}$ ratios that cluster near $8 \pm 1$ Ra (e.g., Graham et al., 1992), the new ${ }^{3} \mathrm{He} /{ }^{4} \mathrm{He}$ measurement suggests that the depleted component in the Pitcairn mantle is unlike the typical upper mantle material sampled at mid-ocean ridges. Instead, this mixing component may be the high ${ }^{3} \mathrm{He} /{ }^{4} \mathrm{He}$ component that is proposed to reside in the lower mantle (Hart et al., 1992).

Based on radiogenic $\mathrm{Sr}-\mathrm{Nd}-\mathrm{Pb}$ isotopic compositions, four distinct mantle componentsEM-1, EM-2, HIMU and the depleted MORB mantleare suggested to encompass the global OIB dataset, and these end-members have 
been plotted as the vertices of a three dimensional tetrahedron in $\mathrm{Sr}-\mathrm{Nd}-\mathrm{Pb}$ isotopic space (e.g., Hart et al., 1992). Each hotspot forms arrays within the tetrahedron that appear to converge on a common component with geochemically depleted Sr and Nd isotopic compositions, and Hart et al. (1992) argued that this component, called FOZO (Focus Zone), is distinct from (i.e., less geochemically-depleted than) the MORB mantle and has high ${ }^{3} \mathrm{He} /{ }^{4} \mathrm{He}$. Indeed, the Pitcairn lava with the highest ${ }^{3} \mathrm{He} /{ }^{4} \mathrm{He}$ is far from being as depleted as the MORB mantle.

Like at other hotspot suites, geochemically-depleted lavas from the Pitcairn hotspot appear to converge on the common component of Hart et al. (1992), but the range of ${ }^{3} \mathrm{He} /{ }^{4} \mathrm{He}$ data in the subset of depleted Pitcairn lavas examined by Honda and Woodhead (2005) were inconsistent with a FOZO component in the Pitcairn hotspot. Instead, Honda and Woodhead (2005) proposed that the MORB-mantle is the depleted component sampled by geochemically-depleted Pitcairn lavas. The new ${ }^{3} \mathrm{He} /{ }^{4} \mathrm{He}$ isotopic data presented here suggest that the depleted component in the Pitcairn mantle is not like the mantle sampled at mid-ocean ridges. Instead, the terrestrial mantle reservoir hosting high ${ }^{3} \mathrm{He} /{ }^{4} \mathrm{He}$, like that sampled by sample Pit-16, is proposed to reside in the lower mantle (Hart et al., 1992). If this is the case, then the depleted Pitcairn component was incorporated into the Pitcairn plume in the lower mantle, and is not a component entrained in the upper mantle. While the ${ }^{3} \mathrm{He} /{ }^{4} \mathrm{He}$ ratios in the geochemically-depleted Pitcairn lavas are not extraordinarily elevated, they do provide hints of a non-MORB component in the geochemically depleted domains of the Pitcairn plume. Honda and Woodhead (2005) showed from neon isotope data that Pitcairn 
samples of clear EM-1 signature had a major component of solar neon, but the data did not fall near the N-MORB correlation line.

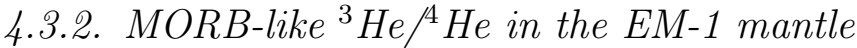

A notable feature of the new dataset is the observation that the Pitcairn lavas with the most geochemically-enriched isotopic signatures have ${ }^{3} \mathrm{He} /{ }^{4} \mathrm{He}$ similar to MORB. The two Pitcairn lavas that have the most extreme EM-1 signatures (i.e., lowest ${ }^{143} \mathrm{Nd} /{ }^{144} \mathrm{Nd}$ and ${ }^{206} \mathrm{~Pb} /{ }^{204} \mathrm{~Pb}$ and highest ${ }^{87} \mathrm{Sr} /{ }^{86} \mathrm{Sr}$ ), and that have also been characterized for helium isotopic ratios, are found to have MORB-like ${ }^{3} \mathrm{He} /{ }^{4} \mathrm{He}$ (Figure 5). However, the other mantle endmembers associated with recycled crustal materials, EM-2 and HIMU, have ${ }^{3} \mathrm{He} /{ }^{4} \mathrm{He}$ ratios lower than MORB, as do lavas from several other hotspot localities (e.g., Tristan, Gough, Comores, Canaries) that do not sample endmember heavy radiogenic isotope compositions (Kurz et al., 1982; Graham et al., 1992; Hanyu and Kaneoka, 1997; Barfod et al., 1999; Class et al., 2005; Jackson et al., 2007a; Parai et al., 2009; Day and Hilton, 2011; Moreira et al., 2011). ${ }^{3} \mathrm{He} /{ }^{4} \mathrm{He}$ ratios range down to $4.3 \mathrm{Ra}$ in Samoan EM-2 lavas with ${ }^{87} \mathrm{Sr} /{ }^{86} \mathrm{Sr}$ of 0.7186 (Jackson et al., 2007a, 2009), and the low ${ }^{3} \mathrm{He} /{ }^{4} \mathrm{He}$ is interpreted to be the result of the incorporation of terrigenous sediment with low ${ }^{3} \mathrm{He} /{ }^{4} \mathrm{He}$ (down to $0.01 \mathrm{Ra}$; Podosek et al., 1980; Ballentine and Burnard, 2002) into peridotitic mantle (>8 Ra); such sediment is U and Th-rich and will generate ${ }^{4} \mathrm{He}$, and the mixture of sediment and mantle peridotite will evolve relatively low ${ }^{3} \mathrm{He} /{ }^{4} \mathrm{He}$ in the EM-2 reservoir over time (Jackson et al., 2009). Similarly, lavas sampling the HIMU mantle generally have ${ }^{3} \mathrm{He} /{ }^{4} \mathrm{He}$ $<7$ Ra (e.g., St. Helena, Mangaia, Tubuai, older series at Rurutu; Graham et al., 1992; Hanyu and Kaneoka, 1997; Parai et al., 2009; Hanyu et al., 2011) 
or $<8$ in OIB with less extreme HIMU signatures (e.g., Canaries; Day and Hilton, 2011). The sub-MORB ${ }^{3} \mathrm{He} /{ }^{4} \mathrm{He}$ ratios may relate to the presence of recycled U and Th-rich oceanic crust into the HIMU mantle (e.g., Hofmann and White, 1982). Note that this U-Th enrichment is opposite to the low $\mathrm{U} / \mathrm{Pb}$ assumed above for the eclogitic component of Koolau EM-1 lavas.If the high HIMU mantle is host to recycled oceanic crust, which is degassed and will have highly radiogenic ${ }^{3} \mathrm{He} /{ }^{4} \mathrm{He}(<0.1 \mathrm{Ra}$; Moreira and Kurz, 2001), an important question is how lavas sampling this mantle reservoir have ${ }^{3} \mathrm{He} /{ }^{4} \mathrm{He}$ that is significantly higher than recycled oceanic crust. A number of solutions have been presented that attempt to explain the observation of sub-MORB ${ }^{3} \mathrm{He} /{ }^{4} \mathrm{He}$ ratios in HIMU lavas that are not as low as degassed oceanic crust (e.g., Hanyu and Kaneoka, 1997; Hanyu et al., 1999; Hilton et al., 2000; Moreira and Kurz, 2001; Class et al., 2005; Hart et al., 2008; Parai et al., 2009; Day and Hilton, 2011; Hanyu et al., 2011; Moreira et al., 2011).

Like the HIMU and EM-2 reservoirs, Pitcairn EM-1 lavas are also suggested to host recycled crustal components, including recycled sediment and oceanic crust. However, Pitcairn EM-1 lavas have MORB-like ${ }^{3} \mathrm{He} /{ }^{4} \mathrm{He}$, which is higher than end-member HIMU and EM-2 lavas and is therefore notable. Recycled crustal materials, like those suggested to exist in the EM1 mantle beneath Pitcairn, should generate ${ }^{4} \mathrm{He}$ by $\mathrm{U}$ and Th decay over time, and this should generate mantle reservoirs with low ${ }^{3} \mathrm{He} /{ }^{4} \mathrm{He}(<0.1 \mathrm{Ra})$. A clue to the apparent paradox of MORB-like ${ }^{3} \mathrm{He} /{ }^{4} \mathrm{He}$ in the Pitcairn may be provided by the higher diffusivity of He relative to the other radiogenic isotopic tracers $(\mathrm{Sr}, \mathrm{Nd}$ and $\mathrm{Pb})$. Owing to the high diffusivity of helium, Hart et al. (2008) suggested that mantle heterogeneities with length-scales 
smaller than 5 to $10 \mathrm{~km}$ will not preserve their helium isotopic signatures over time scales of $1.5 \mathrm{Ga}$, but their $\mathrm{Sr}, \mathrm{Nd}$ and $\mathrm{Pb}$ isotopic signature will remain relatively unchanged. If the recycled sediment heterogeneities in the EM-1 mantle are distributed over relatively short length scales (5 to $10 \mathrm{~km}$ or less), and if the EM-1 mantle is sufficiently old (>1.5 Ga), then the helium isotopic composition of the EM-1 mantle may become overwhelmed by the ${ }^{3} \mathrm{He} /{ }^{4} \mathrm{He}$ signature of the mantle reservoir hosting the recycled materials, here inferred to be ambient upper mantle, which is $8 \mathrm{Ra}$. Of course, this requires that the ${ }^{4} \mathrm{He}$ production of the recycled component is low compared to the ambient mantle helium concentration (Hart et al., 2008). If the time-integrated helium concentrations of the upper mantle greatly exceed the concentrations of the recycled oceanic crust and sediment (Day and Hilton, 2011), and if the length scales of the recycled materials are small $(<<5-10$ km; Hart et al., 2008), the ${ }^{3} \mathrm{He} /{ }^{4} \mathrm{He}$ of the resulting mantle reservoir is more likely to have a ${ }^{3} \mathrm{He} /{ }^{4} \mathrm{He}$ similar to the ambient upper mantle. A diffusive decoupling mechanism like that proposed by Hart et al. (2008) may explain the presence of MORB-like ${ }^{3} \mathrm{He} /{ }^{4} \mathrm{He}$ in a mantle reservoir that hosts recycled oceanic crust and sediments. Because neon diffuses many orders of magnitude slower than helium (in olivine, Cherniak et al., 2014), the solar neon signature of Honda and Woodhead (2005) could be retained in the recycled material while a MORB-like helium is imprinted by diffusive exchange. Of course, a more sinister explanation would simply postulate a helium (but not $\mathrm{Sr}, \mathrm{Nd}$ or $\mathrm{Pb}$ ) isotope exchange in the uppermost mantle between migrating EM-1 melts (or magma chambers) and the ambient MORB mantle country rocks. It is of course possible that EM-1 has the same helium value as MORB 
by coincidence.

\section{Conclusions}

The extreme enriched mantle EM-1 signature in Pitcairn lavas likely hosts an enriched protolith derived from upper continental crust, and this protolith exhibits many geochemical similarities with pelagic sediment. Elevated primary-melt $\mathrm{Ti}$ in the EM-1 lavas suggests the presence of recycled pyroxenite in the mantle source. We identify a tholeiitic sample (65-DS4) from Adams Seamount at the leading edge of the Pitcairn hotspot, and the tholeiitic composition of this sample complements tholeiites previously described from the Pitcairn hotspot. The new tholeiitic Pitcairn seamount sample not only has the highest olivine-corrected $\mathrm{SiO}_{2}$ abundance in the Pitcairn dataset, but it also extends the Pitcairn field closer to the Hawaiian Koolau field in $\mathrm{Pb}$-isotopic space than any previously examined Pitcairn lava. The geochemical affinities suggest there may be broad similaritiesincluding geochemically-enriched $\mathrm{Sr}$ and $\mathrm{Nd}$ isotopic compositions and elevated $\mathrm{SiO}_{2}$ in the mantle sources sampled by tholeiitic Pitcairn lavas and the EM-1 component in Koolau lavas. The origin of the $\mathrm{SiO}_{2}$-rich nature of Koolau lavas from Hawaii is argued to be the result of eclogite melting in the Hawaiian mantle plume. The isotopic and major element affinities between the Pitcairn EM-1 tholeiitic sample 65DS-4 and the EM-1 component sampled by tholeiitic Koolau lavas from Hawaii suggests a common origin, and we argue that a silica-saturated mafic protolith is in the source of the EM-1 mantle at both hotspots. We also present the highest ${ }^{3} \mathrm{He} /{ }^{4} \mathrm{He}(12.6 \mathrm{Ra})$ reported for Pitcairn lavas, and it is associated with a third component with the highest 
${ }^{206} \mathrm{~Pb} /{ }^{204} \mathrm{~Pb}$ and the most geochemically-depleted ${ }^{87} \mathrm{Sr} /{ }^{86} \mathrm{Sr}$ and ${ }^{143} \mathrm{Nd} /{ }^{144} \mathrm{Nd}$ ratios in the Pitcairn suite. We also show that EM-1 end-member lavas from Pitcairn have ${ }^{3} \mathrm{He} /{ }^{4} \mathrm{He}$ that is indistinguishable from the MORB mantle. If the recycled sedimentary and mafic components in the Pitcairn EM-1 occur at relatively short length scales, distributed in a peridotite matrix with ${ }^{3} \mathrm{He} /{ }^{4} \mathrm{He}$ of $8 \mathrm{Ra}$, diffusive exchange of helium over timescales $>1.5 \mathrm{Ga}$ will permit the ${ }^{3} \mathrm{He} /{ }^{4} \mathrm{He}$ of the Pitcairn EM-1 mantle source to evolve toward values that typify the ambient upper mantle sampled by MORB. Alternatively, exchange of helium between EM-1 melts and melt conduits in the upper mantle host rock may result in EM-1 helium isotopic ratios evolving toward values typical of the upper mantle.

\section{Acknowledgements}

We acknowledge the seagoing efforts of Peter Stoffers, the chief scientist during the 1989 cruise of the FS Sonne, and H. Craig, the chief scientist of the Helious Expedition that visited Pitcairn Island in 1989. The authors acknowledge constructive comments from Al Hofmann on a prior version of this manuscript. MGJ acknowledges support from NSF grants OCE-1153894, EAR-1348082, EAR-1347377 and EAR-1145202.

\section{References}

Ballentine C, Burnard P. Production, release and transport of noble gases in the continental crust. Reviews in Mineralogy and Geochemistry $2002 ; 47: 481-538$. 
Barfod D, Ballentine C, Halliday A, Fitton J. Noble gases in the Cameroon line and the He, Ne, and Ar isotopic compositions of high $\mu$ (HIMU) mantle. Journal of Geophysical Research Solid Earth 1999;104:29509-27.

Blichert-Toft J, Frey FA, Albarède F. Hf isotope evidence for pelagic sediments in the source of Hawaiian basalts. Science 1999a;285:879-82.

Brandenburg J, Hauri EH, van Keken PE, Ballentine CJ. A multiple-system study of the geochemical evolution of the mantle with force-balanced plates and thermochemical effects. Earth and Planetary Science Letters 2008;:doi: 10.1016/j.epsl.2008.08.027.

Cabral RA, Jackson MG, Rose-Koga EF, Koga KT, Whitehouse MJ, Antonelli MA, Farquhar J, Day JMD, Hauri EH. Anomalous sulphur isotopes in plume lavas reveal deep mantle storage of Archaean crust. Nature 2013;:doi:10.1038/nature12020.

Carter RM. The geology of Pitcairn Island, South Pacific Ocean. volume 231. Bishop Museum Press, 1967.

Chauvel C, Hofmann AW, Vidal P. HIMU-EM: The French Polynesian Connection. Earth and Planetary Science Letters 1992;110:99-119.

Cherniak D, Thomas J, Watson E. Neon diffusion in olivine and quartz. Chemical Geology 2014;371:68-82.

Class C, Goldstein S, Stute M, Kurz M, Schlosser P, Grand P. Comore island: a well-constrained "low ${ }^{3} \mathrm{He} /{ }^{4} \mathrm{He} "$ mantle plume. Earth and Planetary Science Letters 2005;233:391-409. 
Collerson KD, Williams Q, Ewart AE, Murphy DT. Origin of HIMU and EM1 domains sampled by ocean island basalts, kimberlites and carbonatites: The role of $\mathrm{CO}_{2}$-fluxed lower mantle melting in thermochemical upwellings. Physics of the Earth and Planetary Interiors 2010;181:112-31.

Day J, Hilton D. Origin of ${ }^{3} \mathrm{He} /{ }^{4} \mathrm{He}$ ratios in HIMU-type basalts constrained from Canary Island lavas. Earth and Planetary Science Letters 2011;305:226-34.

Debaille V, Tronnes R, Brandon A, Waight T, Graham D, Lee CTA. Primitive off-rift basalts from Iceland and Jan Mayen: Os isotopic evidence for a mantle source containing enriched subcontinental lithosphere. Geochimica et Cosmochimica Acta 2009;73:3423-49.

Duncan R, McDougall I, Carter R, Coombs D. Pitcairn island - another Pacific hot spot? Nature 1974;251:619-82.

Eiler J, Farley K, Valley J, Hauri EH, Craig H, Hart S, Stolper E. Oxygen isotope variations in ocean island basalt phenocrysts. Geochimica et Cosmochimica Acta 1997;61:2281-93.

Eiler JM, Farley KA, Valley JW, Stolper EM, Hauri EH, Craig H. Oxygen isotope evidence against bulk recycled sediment in the mantle sources of Pitcairn island lavas. Nature 1995;377:138-41.

Eisele J, Sharma M, Galer SJG, Blichert-Toft J, Devey CW, Hofmann AW. The role of sediment recycling in EM-1 inferred from Os, $\mathrm{Pb}, \mathrm{Hf}, \mathrm{Nd}, \mathrm{Sr}$ isotope and trace element systematics of the Pitcairn hotspot. Earth and Planetary Science Letters 2002;196:197-212. 
Escrig S, Capmas F, Dupre B, Allegre CJ. Osmium isotopic constraints on the nature of the DUPAL anomaly from Indian mid-ocean-ridge basalts. Nature 2004;:doi:10.1038/nature02904.

Farley K, Basu A, Craig H. He, Sr and Nd isotopic variations in lavas from the Juan Fernandez Archipelago, SE Pacific. Contributions to Mineralogy and Petrology 1993;115:75-87.

Farley KA, Natland JH, Craig H. Binary mixing of enriched and undegassed (primitive?) mantle components ( $\mathrm{He}, \mathrm{Sr}, \mathrm{Nd}, \mathrm{Pb}$ ) in Samoan lavas. Earth and Planetary Science Letters 1992;111:183-99.

Gasperini D, Blichert-Toft J, Bosch D, DelMoro A, D.Macera , Télouk P, Albarède F. Evidence from Sardinian basalt geochemistry for recycling of plume heads into the Earth's mantle. Nature 2000;408:701-4.

Gast PW, Tilton GR, Hedge C. Isotopic composition of lead and strontium from Ascension and Gough Islands. Science 1964;:10.1126/science.145.3637.1181.

Geldmacher J, Hoernle K, Klügel A, van den Bogaard P, Bindeman I. Geochemistry of a new enriched mantle type locality in the northern hemisphere: Implications for the origin of the EM-I source. Earth and Planetary Science Letters 2008;

Graham DW, Humphris SE, Jenkins WJ, Kurz MD. Helium isotope geochemistry of some volcanic rocks from Saint Helena. Earth and Planetary Science Letters 1992;110:121-31. 
Guillou H, Garcia M, Turpin L. Unspiked K-Ar dating of young volcanic rocks from Loihi and Pitcairn hot spot seamounts. Journal of Volcanology and Geothermal Research 1997;78:239-49.

Hanan BB, Blichert-Toft J, Pyle DG, Christie DM. Contrasting origins of the upper mantle revealed by hafnium and lead isotopes from the Southeast Indian Ridge. Nature 2004;432:91-4.

Hanan BB, Graham DW. Lead and Helium Isotope Evidence from Oceanic Basalts for a Common Deep Source of Mantle Plumes. Science 1996;:991-5.

Hanyu T, Kaneoka I. The uniform and low ${ }^{3} \mathrm{He} /{ }^{4} \mathrm{He}$ ratios of HIMU basalts as evidence for their origin as recycled materials. Nature 1997;:doi:10.1038/36835.

Hanyu T, Kaneoka I, Nagao K. Noble gas study of HIMU and EM ocean island basalts in the Polynesian region. Geochimica et Cosmochimica Acta 1999;63:1181-201.

Hanyu T, Kawabata H, Tatsumi Y, Kimura JI, Hyodo H, Sato K, Miyazaki T, Chang Q, Hirahara Y, Takahashi T, Senda R, Nakai S. Isotope evolution in the HIMU reservoir beneath St. Helena: Implications for the mantle recycling of U and Th. Geochimica et Cosmochimica Acta 2014;143:23252.

Hanyu T, Tatsumi Y, Kimura JI. Constraints on the origin of the HIMU reservoir from $\mathrm{He}-\mathrm{Ne}-\mathrm{Ar}$ isotope systematics. Earth and Planetary Science Letters 2011;307:377-86. 
Hart SR. The Mantle Zoo: New Species, Endangered Spieces, Extinct Species. Mineralogical Magazine 2011;3:983.

Hart SR, Blusztajn JS. Age and geochemistry of the mafic sills, ODP site 1276, Newfoundland margin. Chemical Geology 2006;235(34):doi:10.1016/j.chemgeo.2006.07.001.

Hart SR, Hauri EH, Oschmann LA, Whitehead JA. Mantle Plumes and Entrainment: Isotopic Evidence. Science 1992;:10.1126/science.256.5056.517.

Hart SR, Kurz M, Wang Z. Scale length of mantle heterogeneities: Constraints from helium diffusion. Earth and Planetary Science Letters 2008;:DOI:10.1016/j.epsl.2008.03.010.

Hauri EH. Major-element variability in the Hawaiian mantle plume. Nature $1996 ; 382: 415-9$.

Hauri EH, Hart SR. Re-Os isotope systematics of HIMU and EMII oceanic island basalts from the south Pacifc Ocean. Earth and Planetary Science Letters 1993;(114):353-71.

Hauri EH, Kurz M. Melt migration and mantle chromatography, 2: a time series Os isotope study of Mauna Loa volcano, Hawaii. Earth and Planetary Science Letters 1997;153:21-36.

Hekinian R, Cheminee JL, Dubois J, Stoffers P, Scott S, Guivel C, GarbeSchonberg D, Devey C, Bourdon B, Lackschewitz K, McMurty G, Drezen EL. The Pitcairn hotspot in the South Pacifc: distribution and composition of submarine volcanic sequences. Journal of Volcanology and Geothermal Research 2003;121:219-45. 
Herzberg C. Petrology and thermal structure of the Hawaiian plume from Mauna Kea volcano. Nature 2006;444:doi:10.1038/nature05254.

Herzberg C. Identification of Source Lithology in the Hawaiian and Canary Islands: Implications for Origins. Journal of Petrology 2011;:113-46.

Hilton D, Macpherson C, Elliott T. Helium isotope ratios in mafic phenocrysts and geothermal fluids from La Palma, the Canary Islands (Spain): implications for HIMU mantle sources. Geochimica et Cosmochimica Acta 2000;64:2119-32.

Hofmann AW. Mantle geochemistry: the message from oceanic volcanism. Nature 1997;385:226-9.

Hofmann AW. Sampling mantle heterogeneity through oceanic basalts: Isotopes and trace elements. In: Carlson RW, editor. The Mantle and Core. New York: Elsevier; volume 2 of Treatise on Geochemistry; 2003. p. 1-44.

Hofmann AW, White WM. Mantle plumes from ancient oceanic crust. Earth and Planetary Science Letters 1982;57:421-36.

Honda M, Woodhead JD. A primordial solar-neon enriched component in the source of EM-I-type ocean island basalts from the Pitcairn Seamounts, Polynesia. Earth and Planetary Science Letters 2005;:597-612.

Huang S, Frey FA. Recycled oceanic crust in the Hawaiian Plume: evidence from temporal geochemical variations within the Koolau Shield. Contributions to Mineralogy and Petrology 2005;149:556-75. 
Jackson MG, Dasgupta R. Compositions of HIMU, EM1, and EM2 from global trends between radiogenic isotopes and major elements in ocean island basalts. Earth and Planetary Science Letters 2008;276:175-86.

Jackson MG, Hart SR, Koppers AAP, Staudigel H, Konter J, Blusztajn J, Kurz M, Russell JA. The return of subducted continental crust in Samoan lavas. Nature 2007a;448:doi:10.1038/nature06048.

Jackson MG, Hart SR, Saal AE, Shimizu N, Skovgaard AC. Globally elevated titanium, tantalum, and niobium (TITAN) in ocean island basalts with high ${ }^{3} \mathrm{He} /{ }^{4} \mathrm{He}$. Geochemistry, Geophysics, Geosystems 2008;Q04027:doi:10.1029/2007GC001876.

Jackson MG, Kurz MD, Hart SR. Helium and neon isotopes in phenocrysts from Samoan lavas: Evidence for heterogeneity in the terrestrial high ${ }^{3} \mathrm{He} /{ }^{4} \mathrm{He}$ mantle. Earth and Planetary Science Letters 2009;287:519-28.

Jackson MG, Shirey SB. Re-Os systematics in Samoan shield lavas and the use of Os-isotopes in olivine phenocrysts to determine primary magmatic compositions. Earth and Planetary Science Letters 2011;312:91-101.

Jackson MG, Weis D, Huang S. Major element variations in Hawaiian shield lavas: Source features and perspectives from global ocean island basalt (OIB) systematics. Geochemistry, Geophysics, Geosystems 2012;13(9):doi:10.1029/2012GC004268.

Johnson D, Hooper P, Conrey R. XRF analysis of rocks and minerals for major and trace elements on a single low dilution Li-tetraborate fused bead. Advances in X-ray Analysis 1999;41:843-67. 
Kawabata H, Hanyu T, Chang Q, Kimura JI, Nichols A, Tatsumi Y. The Petrology and geochemistry of St. Helena alkali basalts: Evaluation of the oceanic crust-recycling model for HIMU OIB. Journal of Petrology 2011;52:doi:10.1093/petrology/egr003.

Knaack C, Cornelius S, Hooper P. Trace element analyses of rocks and minerals by ICP-MS. open-file report; Washington State University; 1994.

Kurz M, Jenkins W, Hart S. Helium isotopic systematics of oceanic islands and mantle heterogeneity. Nature 1982;297:43-7.

Lassiter JC, Hauri EH. Osmium-isotope variations in Hawaiian lavas: evidence for recycled oceanic lithosphere in the Hawaiian plume. Earth and Planetary Science Letters 1998;164:483-96.

Macdonald GA, Katsura T. Chemical Composition of Hawaiian Lavas. Journal of Petrology 1964;5:doi: 10.1093/petrology/5.1.82.

Mahoney J, Nicollet C, Dupuy C. Madagascar basalts - tracking oceanic and continental sources. Earth and Planetary Science Letters 1991;104:350-63.

McKenzie D, O’Nions RK. Mantle reservoirs and ocean island basalts. Nature 1983;301:229-31.

Menzies M. Mantle Ultramafic Xenoliths in Alkaline Magmas: Evidence for Mantle Heterogeneity Modified by Magmatic Activity. In: Continental Basalts and Mantle Xenoliths. Shiva Publishing; 1983. p. 92-110.

Menzies M, Murthy VR. Nd and Sr isotope geochemistry of hydrous mantle nodules and their host alkali basalts: Implications for local heterogeneities 
in metasomatically veined mantle. Earth and Planetary Science Letters 1980;46:323-34.

Moreira M, Kanzari A, Madureira P. Helium and neon isotopes in São Miguel island basalts, Azores Archipelago: New constraints on the "low ${ }^{3} \mathrm{He}$ " hotspot origin. Chemical Geology 2011;322-323:91-8.

Moreira M, Kurz M. Subducted oceanic lithosphere and the origin of the 'high $\mu$ ' basalt helium isotopic signature. Earth and Planetary Science Letters 2001;189:49-57.

Niu Y, O'Hara MJ. Origin of ocean island basalts: A new perspective from petrology, geochemistry, and mineral physics considerations. Journal of Geophysical Research 2003;:doi:10.1029/2002JB002048.

Parai R, Mukhopadhyay S, Lassiter JC. New constraints on the HIMU mantle from neon and helium isotopic compositions of basalts from the CookAustral Islands. Earth and Planetary Science Letters 2009;277:253-61.

Pilet S, Baker MB, Müntener O, Stolper EM. Monte Carlo Simulations of Metasomatic Enrichment in the Lithosphere and Implications for the Source of Alkaline Basalts. Journal of Petrology 2011;:doi:10.1093/petrology/egr007.

Plank T, Langmuir CH. The chemical composition of subducting sediment and its consequences for the crust and mantle. Chemical Geology 1998;145:325-94.

Podosek F, Honda M, Ozima M. Sedimentary noble gases. Geochimica et Cosmochimica Acta 1980;44:1875-84. 
Prytulak J, Elliot T. $\mathrm{TiO}_{2}$ enrichment in ocean island basalts. Earth and Planetary Science Letters 2007;263:388-403.

Rehkämper M, Hofmann AW. Recycled ocean crust and sediment in Indian Ocean MORB. Earth and Planetary Science Letters 1997;147:93-106.

Reisberg L, Zindler A, Marcantonio F, White W, Wyman D, Weaver B. Os isotope systematics in ocean island basalts. Earth and Planetary Science Letters 1993;120:149-67.

Rhodes J. Geochemistry of the 1984 Mauna Loa eruption: Implications for magma storage and supply. Journal of Geophysical Research 1988;93:4,453-454,466.

Rudnick RL, Gao S. Composition of the continental crust. In: Rudnick RL, editor. Treatise on Geochemistry. New York: Elsevier; volume 3; 2003. p. $1-64$.

Salters VJ, Sachi-Kocher A. An ancient metasomatic source for the Walvis Ridge basalts. Chemical Geology 2010;:10.1016/j.chemgeo.2010.02.010.

Shirey S, Walker R. Carius tube digestion for low-blank rhenium-osmium analysis. Analytical Chemistry 1995;67(13):2136-41.

Sobolev AV, Hofmann AW, Sobolev SV, Nikogosian IK. An olivine-free mantle source of Hawaiian shield basalts. Nature 2005;:590-7.

Stoffers P, Hekinian R, Ackermand D, Binard N, Botz R, Devey C, Hansen D, Hodkinson R, Jeschke G, Lange J, v Perre E, Scholten J, Schmitt M, 
Sedwick P, Woodhead JD. Active Pitcairn hotspot found. Marine Geology 1990;95:51-5.

Stracke A. Earth's heterogeneous mantle: A product of convection-driven interaction between crust and mantle. Chemical Geology 2012;330331(10):opagesdoi:10.1016/j.chemgeo.2012.08.007.

Tatsumi Y. Continental crust formation by crustal delamination in subduction zones and complementary accumulation of the enriched mantle I component in the mantle. Geochemistry, Geophysics, Geosystems 2000;1:doi: 10.1029/2000GC000094.

Todt W, Cliff RA, Hanser A, Hofmann AW. Evaluation of a ${ }^{202} \mathrm{~Pb}-{ }^{205} \mathrm{~Pb}$ double spike for high precision lead isotope analysis. In: Basu A, Hart SR, editors. Earth processes: reading the isotopic code. AGU Geophysical Monograph; volume 95; 1996. p. doi: 10.1029/GM095P0429.

Weaver BL. The origin of ocean island basalt end-member compositions: trace element and isotopic constraints. Earth and Planetary Science Letters 1991;104:381-97.

White WM. Oceanic Island Basalts and Mantle Plumes: The Geochemical Perspective. In: Annual Review of Earth and Planetary Sciences. Annual Reviews; 2010. p. 10.1146/annurev-earth.

Willbold M, Stracke A. Formation of enriched mantle components by recycling of upper and lower continental crust. Chemical Geology 2010;276:188-97. 
Woodhead JD, Devey CW. Geochemistry of the Pitcairn seamounts, I: source character and temporal trends. Earth and Planetary Science Letters $1993 ;: 81-99$.

Woodhead JD, GreenWood P, Harmon RS, Stoffers P. Oxygen isotope evidence for recycled crust in the source of EM-type ocean island basalts. Nature 1993;362:doi:10.1038/362809a0.

Woodhead D, McCulloch MT. Ancient seafloor signals in Pitcairn Island lavas and evidence for large amplitude, small length-scale mantle heterogeneities. Earth and Planetary Science Letters 1989;94:257-73.

Workman RK, Eiler JM, Hart SR, Jackson MG. Oxygen isotopes in Samoan lavas: Confirmation of continent recycling. Geology 2008;:doi: 10.1130/G24558A.1.

Workman RK, Hart SR, Jackson MG, Regelous M, Farley KA, Blusztajn J, Kurz J, Staudigel H. Recycled metasomatized lithosphere as the origin of the Enriched Mantle II (EM2) end-member: Evidence from the Samoan Volcanic Chain. Geochemistry, Geophysics, Geosystems 2004;:doi: 10.1029/2003GC000623.

Zindler A, Hart S. Chemical Geodynamics. Ann Rev Earth Planet Sci $1986 ; 14: 493-571$.

Zindler A, Jagoutz E, Goldstein S. Nd, Sr and Pb isotopic systematics in a three-component mantle: A new perspective. Nature 1982;1036(298):51923. 


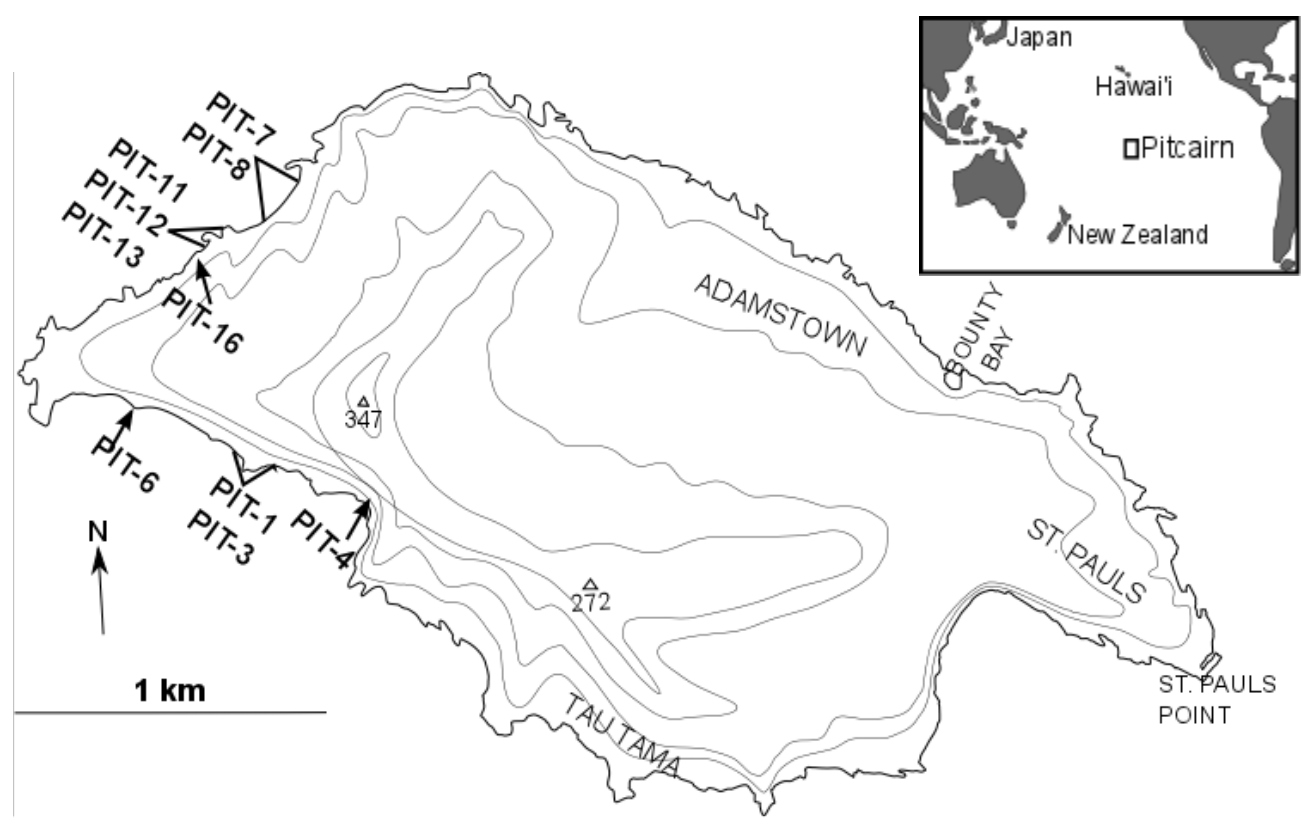

Figure 1: Map of Pitcairn island with sample locations from this study. The subaerial samples, and the single submarine sample, were collected prior to GPS availability. The submarine sample 65DS-4 was obtained from volcano 1 located $\sim 90 \mathrm{~km}$ ESE of Pitcairn. 


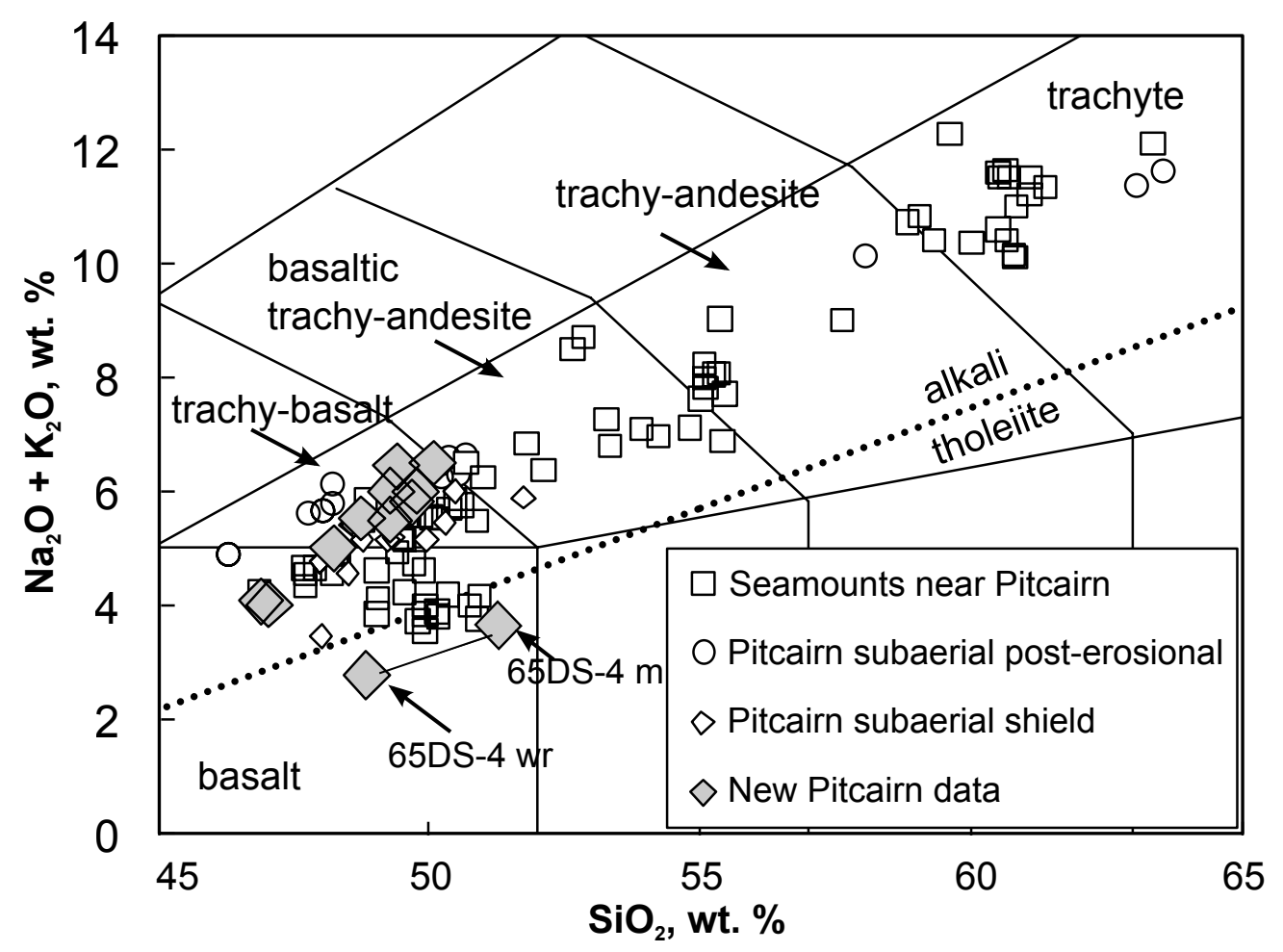

Figure 2: TAS diagram shows that Pitcairn lavas are prevailingly alkalic, but some seamount samples are slightly tholeiitic and cross the alkali-tholeiite divide. The new data for Pitcairn seamount sample 65DS-4 show that it is a tholeiite (whole rock and matrix data are shown for this sample). The previously published data shown in this figure (and in all subsequent figures) were obtained from the GEOROC database (http://georoc.mpchmainz.gwdg.de/georoc) on October 1, 2013 and verified with the original references. 

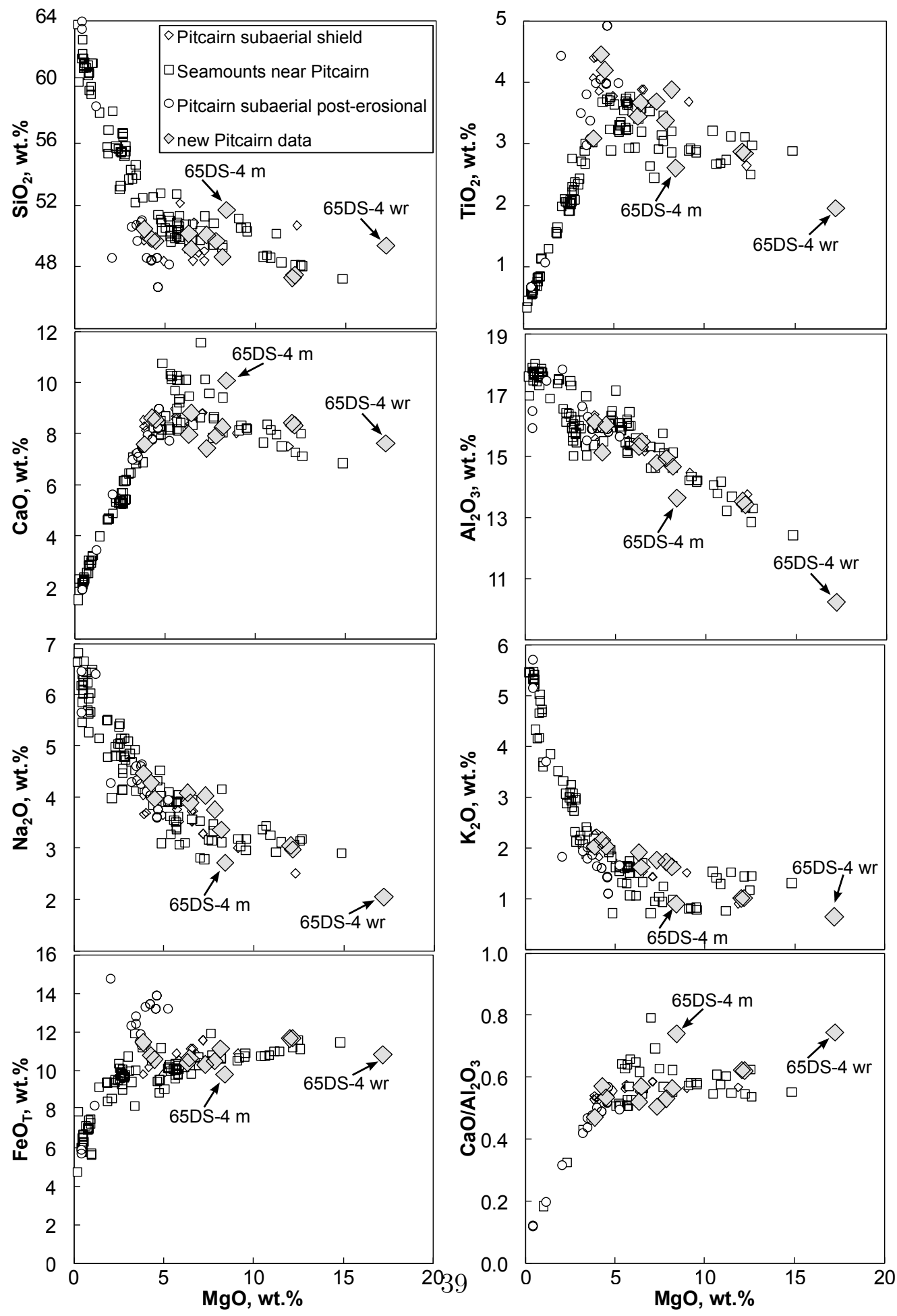

Figure 3 
Variation diagrams of major element oxides for all Pitcairn lavas. The data are normalized to $100 \mathrm{wt}$. \% on a dry basis. Olivine dominates the major element variations for bulk rock composition where $\mathrm{MgO}>8-10$ wt. \%. At $\mathrm{MgO}<8-10 \mathrm{wt}$. \%, clinopyroxene fractionation is apparent from reduced $\mathrm{CaO} / \mathrm{Al}_{2} \mathrm{O}_{3}$ ratios. Fractionation of Fe- and Ti-rich phases is evident in lavas with $\mathrm{MgO}<5$ wt. \%. For some of the seamount samples, both whole rock and glass data are plotted when it was available on the same sample. For 65DS-4 whole rock (65DS-4 wr) and matrix (65DS-4 m) are plotted separately. 

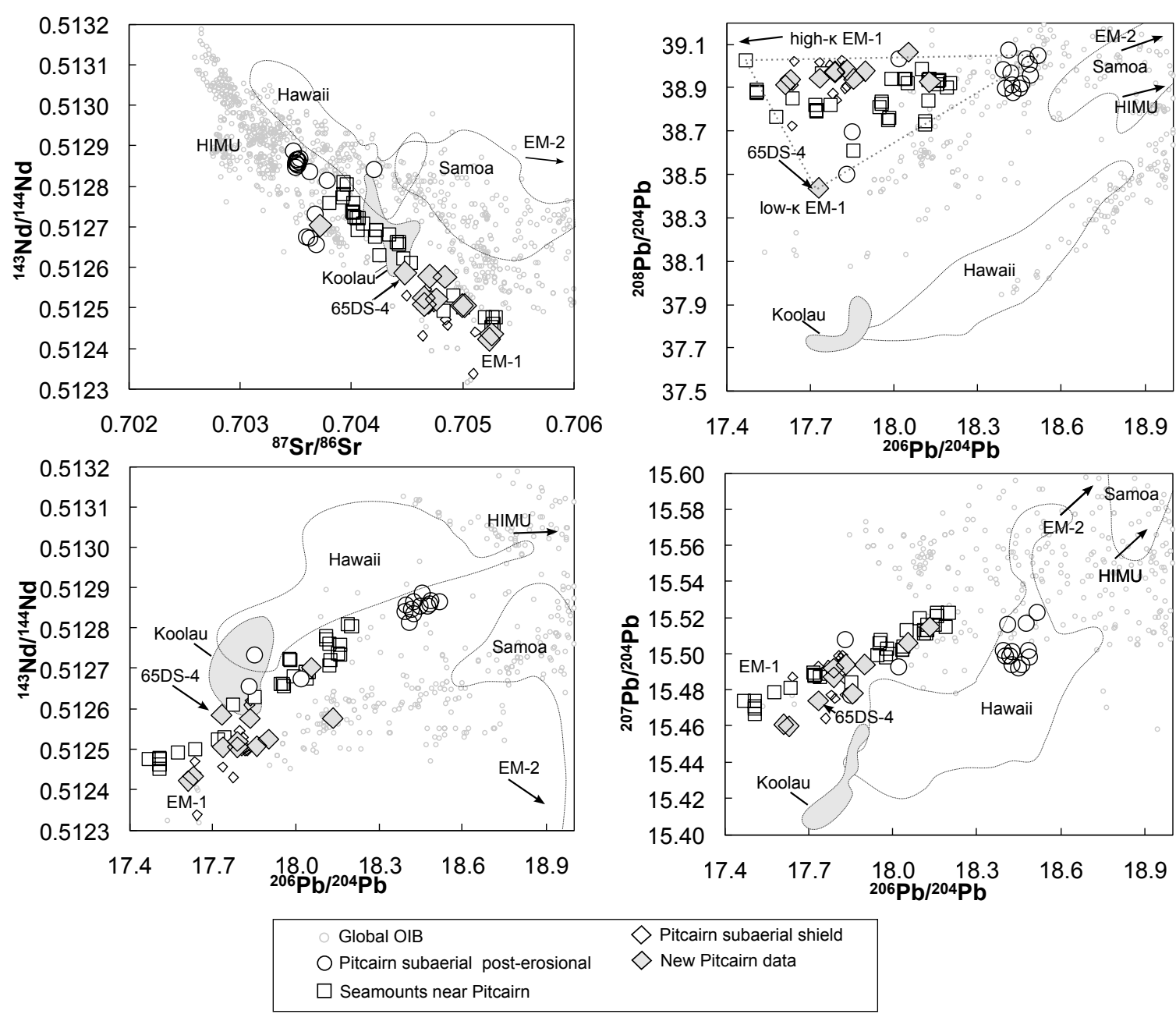

Figure 4: Isotopic data for Pitcairn lavas reveal a typical EM-1 signature: low ${ }^{143} \mathrm{Nd} /{ }^{144} \mathrm{Nd}$, moderately high ${ }^{87} \mathrm{Sr} /{ }^{86} \mathrm{Sr}$ and highly unradiogenic ${ }^{206} \mathrm{~Pb} /{ }^{204} \mathrm{~Pb}$. The plot of ${ }^{208} \mathrm{~Pb} /{ }^{204} \mathrm{~Pb}$ against ${ }^{206} \mathrm{~Pb} /{ }^{204} \mathrm{~Pb}$ reveals the presence of a third component in Pitcairn lavas, which is the second component that is highlighted in the dashed triangle. The third component (called low- $\kappa$ EM-1) is anchored by geochemically-more depleted rejuvenated lavas. Data fields for Samoa and Hawaii (including Koolau volcano) are shown with the global OIB database, and these data are taken from Georoc database and verified with the original references. The Pitcairn isotopic data are from the following sources: (Woodhead and McCulloch, 1989; Woodhead and Devey, 1993; Woodhead et al., 1993; Eisele et al., 2002; Honda and Woodhead, 2005). 


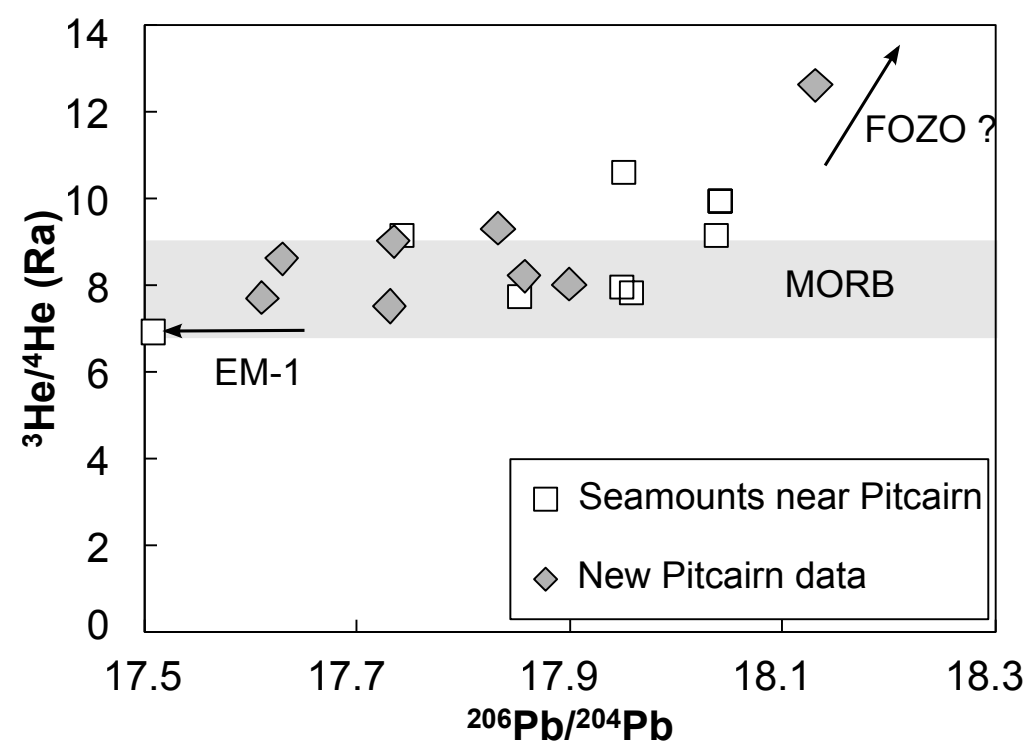

Figure 5: ${ }^{3} \mathrm{He} /{ }^{4} \mathrm{He}$ ratios and He concentrations in olivine (in subaerial samples, reported here for the first time) and seamount glasses (reported in Honda and Woodhead, 2005). Only the data for glasses with ${ }^{4} \mathrm{He}>10^{-7} \mathrm{cc}$ $\mathrm{STP} / \mathrm{g}$ are plotted in the right panel. The line in the left panel connects two replicate measurements on coarse and fine olivine fractions (sample PIT-16). The diagram to the right shows that the sample with the highest ${ }^{3} \mathrm{He} /{ }^{4} \mathrm{He}$ ratio (which is shown as the average of two measurements of this sample, 11.8 Ra and 13.3 Ra, measured on coarse and fine olivine fractions, respectively) also has the weakest EM-1 signature and instead trends towards the depleted mantle component (FOZO?) sampled by Pitcairn lavas. The two lavas with the lowest ${ }^{206} \mathrm{~Pb} /{ }^{204} \mathrm{~Pb}$ have the lowest ${ }^{3} \mathrm{He} /{ }^{4} \mathrm{He}$ ratios, $7.7 \mathrm{Ra}$ (measured in a glass) and $8.0 \mathrm{Ra}$ (measured in olivine), indicating MORB-like ${ }^{3} \mathrm{He} /{ }^{4} \mathrm{He}$ signature in the EM-1 mantle. 


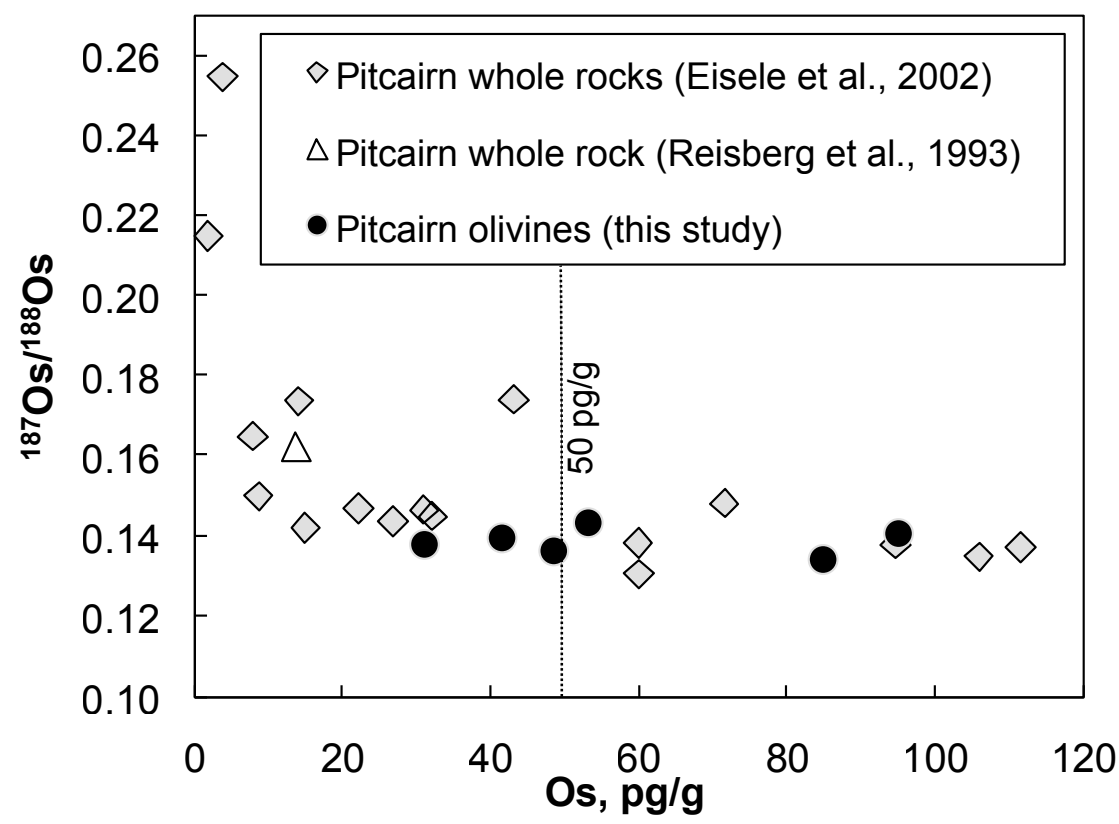

Figure 6: The new olivine ${ }^{187} \mathrm{Os} /{ }^{188} \mathrm{Os}$ measurements in this study fall in the same range as identified in the most Os-rich whole rocks (>50 pg/g; Eisele et al., 2002) and support the previous observations that the EM-1 end-member has radiogenic Os, which is consistent with a recycled origin for EM-1 lavas in Pitcairn (Eisele et al., 2002). 


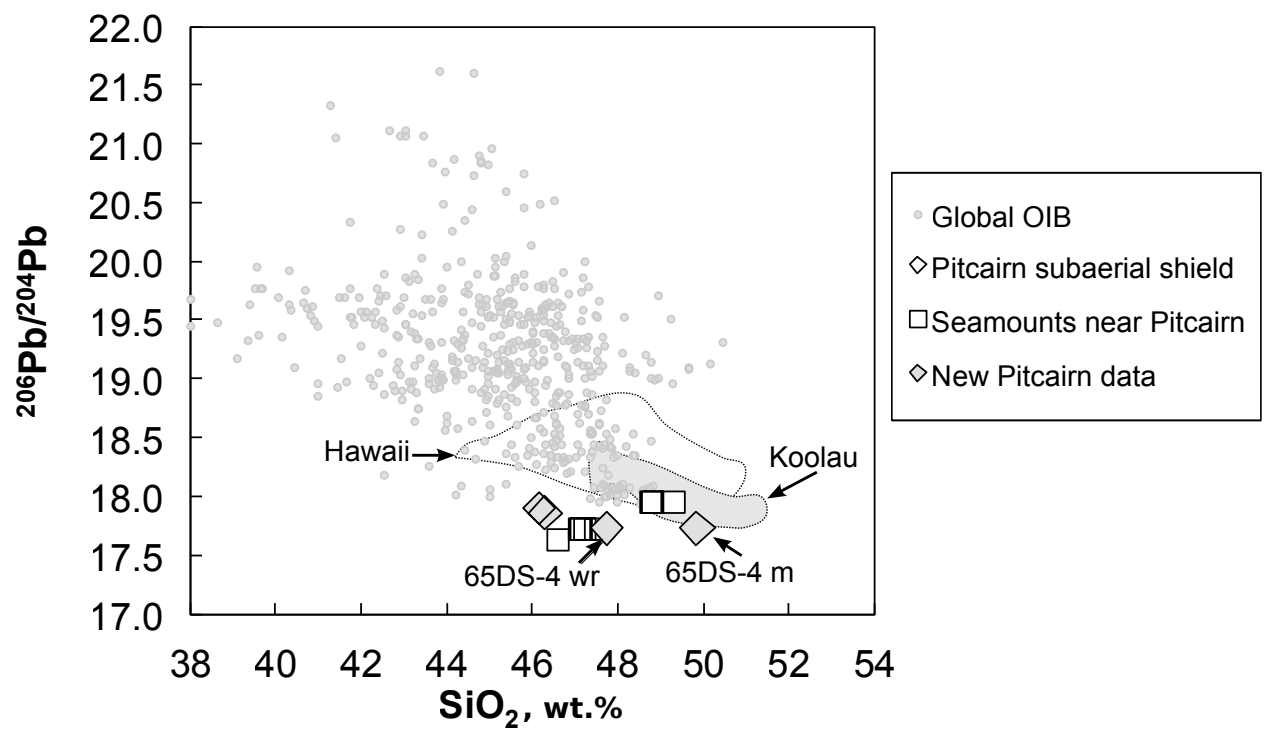

Figure 7: ${ }^{206} \mathrm{~Pb} /{ }^{204} \mathrm{~Pb}$ plotted against the major element compositions of Pitcairn lavas, the Hawaiian dataset is from Jackson et al. (2012) and the global OIB dataset from Jackson and Dasgupta (2008). With the exception of sample 65-DS-4 matrix, the displayed Pitcairn data shows only data with $\mathrm{MgO}>9 \%$, and all lavas are olivine fractionation corrected by the addition or subtraction of equilibrium olivine so that they were in equilibrium with mantle olivine (forsterite 90). The data shows that, together with Hawaii, Pitcairn seamount lavas anchor the high $\mathrm{SiO}_{2}$-rich portion of the Pitcairn array. 


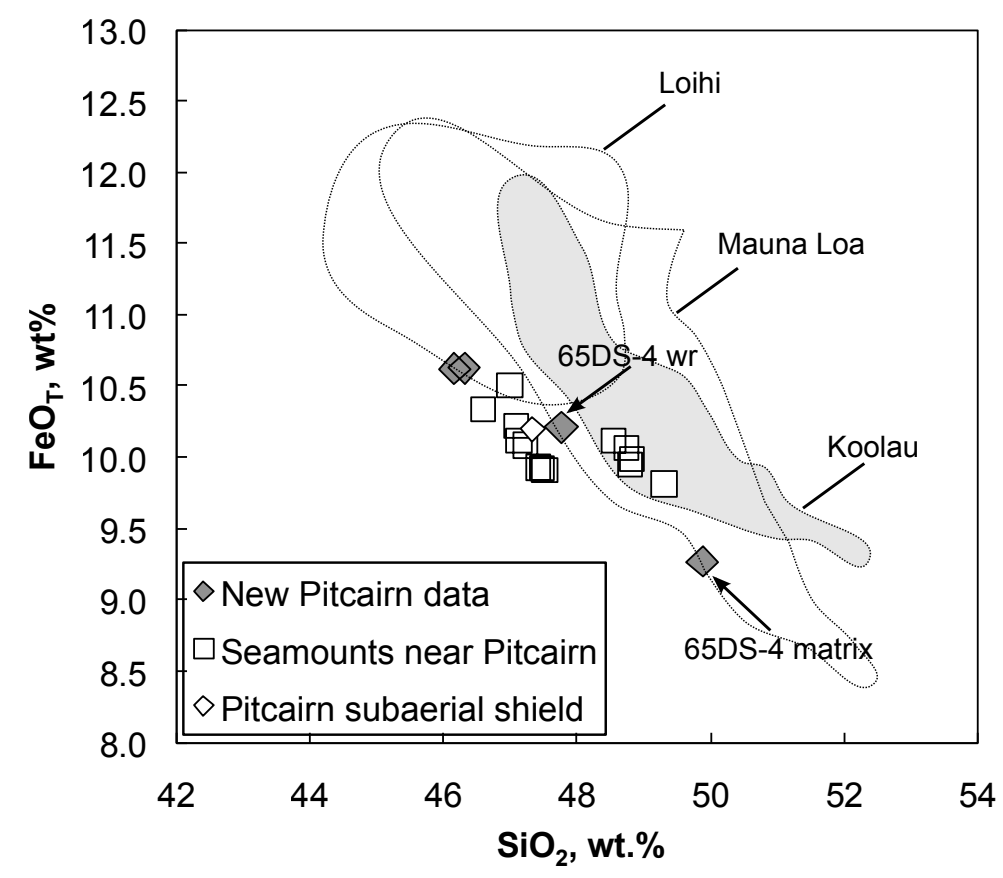

Figure 8: $\mathrm{FeO}_{T}$ plotted against $\mathrm{SiO}_{2}$ of Pitcairn lavas and Mauna Loa, Koolau and Loihi from Hawaiian dataset (obtained from GEOROC database on March 13, 2014.). All lavas are olivine fractionation corrected by the addition or subtraction of equilibrium olivine so that they were in equilibrium with mantle olivine (forsterite 90). With the exception of sample 65-DS-4 matrix, the displayed Pitcairn data have $\mathrm{MgO}>9 \%$, and Hawaiian data have $\mathrm{MgO}>6.5 \%$. 
Table 1: Whole rock major, trace and isotope analyses for Pitcairn samples from this study, and Os-isotopic analyses on olivines.

\begin{tabular}{|c|c|c|c|c|c|c|c|c|c|c|c|c|}
\hline & 65DS-4 (wr) & 65DS-4 (m) & PIT-1 & PIT-3 & PIT-4A & PIT-6 & PIT-7 & PIT-8 & PIT-11 & PIT-12 & PIT-13 & PIT-16* \\
\hline $\mathrm{SiO}_{2}$ (wt.\%) & 48.59 & 51.15 & 48.10 & 48.73 & 48.91 & 49.54 & 48.15 & 46.32 & 46.45 & 49.22 & 47.47 & 48.71 \\
\hline $\mathrm{TiO}_{2}$ & 1.88 & 2.53 & 3.50 & 3.27 & 4.34 & 2.99 & 3.55 & 2.77 & 2.74 & 3.34 & 3.75 & 4.08 \\
\hline $\mathrm{Al}_{2} \mathrm{O}_{3}$ & 10.14 & 13.58 & 14.30 & 14.76 & 14.97 & 15.96 & 15.28 & 13.35 & 13.24 & 15.14 & 14.42 & 15.82 \\
\hline $\mathrm{FeO}_{\mathrm{T}}$ & 10.74 & 9.79 & 9.99 & 10.39 & 10.68 & 11.35 & 10.52 & 11.52 & 11.53 & 10.31 & 10.94 & 10.46 \\
\hline $\mathrm{CaO}$ & 7.55 & 10.05 & 7.20 & 7.82 & 8.53 & 7.50 & 8.69 & 8.31 & 8.21 & 7.87 & 8.12 & 8.45 \\
\hline MgO & 17.09 & 8.39 & 7.10 & 7.77 & 4.25 & 3.83 & 6.39 & 11.91 & 12.03 & 6.27 & 8.06 & 4.45 \\
\hline MnO & 0.30 & 0.27 & 0.15 & 0.15 & 0.17 & 0.21 & 0.16 & 0.17 & 0.17 & 0.16 & 0.16 & 0.17 \\
\hline $\mathrm{K}_{2} \mathrm{O}$ & 0.63 & 0.88 & 1.70 & 1.70 & 2.13 & 2.00 & 1.59 & 0.98 & 0.99 & 1.88 & 1.59 & 2.00 \\
\hline $\mathrm{Na}_{2} \mathrm{O}$ & 2.04 & 2.71 & 3.90 & 3.71 & 4.23 & 4.42 & 3.84 & 3.02 & 2.94 & 4.04 & 3.31 & 3.92 \\
\hline $\mathrm{P}_{2} \mathrm{O}_{5}$ & 0.26 & 0.36 & 0.90 & 0.62 & 0.82 & 1.17 & 0.60 & 0.43 & 0.42 & 0.73 & 0.61 & 0.79 \\
\hline Total & 99.22 & 99.71 & 96.84 & 98.92 & 99.03 & 98.97 & 98.77 & 98.78 & 98.72 & 98.96 & 98.43 & 98.85 \\
\hline $\begin{array}{l}\text { olivine } X_{\mathrm{Fo}} \\
\text { plagioclase } \mathrm{X}_{\mathrm{Ar}}\end{array}$ & 84.7 & & $\begin{array}{l}80.1 \\
N A\end{array}$ & 80.2 & $\overline{N A}$ & & $\begin{array}{l}76.5 \\
58.6\end{array}$ & $\begin{array}{l}82 \\
-\end{array}$ & $\begin{array}{c}80.6 \\
-\end{array}$ & $\begin{array}{l}81.3 \\
62.7\end{array}$ & $\begin{array}{l}79.5 \\
72.1\end{array}$ & $\begin{array}{l}75.7 \\
57.8\end{array}$ \\
\hline \multicolumn{13}{|l|}{ XRF } \\
\hline $\mathrm{Rb}$ (ppm) & 6.0 & & 30.8 & 32.5 & 41.7 & 42.5 & 28.2 & 18.0 & 18.1 & 34.8 & 26.7 & 37.0 \\
\hline $\mathrm{Sr}$ & 343 & & 669 & & 616 & 593 & 595 & 528 & 519 & 666 & 656 & 562 \\
\hline $\mathrm{Zn}$ & 103 & & 111 & 113 & 140 & 154 & 15 & 123 & 123 & 124 & 124 & 121 \\
\hline $\mathrm{Ni}$ & 556 & & 180 & 180 & 47 & 14 & 105 & 311 & 312 & 102 & 165 & 54 \\
\hline $\mathrm{Cr}$ & 962 & & 221 & 231 & 15 & 1 & 141 & 434 & 428 & 108 & 201 & 56 \\
\hline v & 163 & & 177 & 171 & 251 & 116 & 226 & 199 & 198 & 207 & 222 & 238 \\
\hline $\mathrm{Ba}$ & 134 & & 474 & 487 & 560 & 302 & 434 & 288 & 289 & 541 & 474 & 568 \\
\hline$Y$ & 20 & & 28 & 30 & 38 & 47 & 30 & 22 & 22 & 33 & 29 & 43 \\
\hline $\mathrm{Nb}$ & 13 & & 44 & 46 & 67 & 76 & 48 & 34 & 34 & 54 & 50 & 61 \\
\hline $\mathrm{Zr}$ & 144 & & 308 & 318 & 439 & 504 & 325 & 220 & 218 & 364 & 328 & 397 \\
\hline \multicolumn{13}{|l|}{ ICP-MS } \\
\hline Cs (ppm) & 0.08 & & 0.16 & 0.14 & 0.63 & 0.33 & 0.13 & 0.06 & 0.10 & 0.25 & 0.11 & 0.13 \\
\hline $\mathbf{R b}$ & 7.4 & & 32.5 & 31.4 & 44.2 & 42.5 & 29.4 & 17.7 & 19.5 & 34.5 & 27.5 & 37.5 \\
\hline $\mathrm{Ba}$ & 125 & & 467 & 460 & 567 & 283 & 412 & 273 & 285 & 492 & 468 & 544 \\
\hline Th & 1.39 & & 6.59 & 7.64 & 8.44 & 9.47 & 6.24 & 4.35 & 4.40 & 8.12 & 7.02 & 7.60 \\
\hline u & 0.38 & & 1.15 & 1.31 & 1.58 & 2.00 & 0.88 & 0.66 & 0.78 & 0.97 & 0.80 & 1.42 \\
\hline $\mathrm{Nb}$ & 11.7 & & 50.6 & 47.1 & 66.8 & 75.1 & 51.1 & 34.3 & 34.8 & 55.3 & 51.3 & 61.4 \\
\hline $\mathrm{Ta}$ & 0.80 & & 2.35 & 2.46 & 3.38 & 4.00 & 2.58 & 1.76 & 1.81 & 2.91 & 2.72 & 3.15 \\
\hline La & 15.1 & & 51.1 & 52.2 & 62.1 & 67.8 & 46.7 & 30.5 & 31.7 & 56.1 & 50.9 & 62.2 \\
\hline $\mathrm{Ce}$ & 34.5 & & 98.4 & 104.2 & 124.3 & 139.5 & 94.7 & 63.7 & 63.8 & 114.2 & 100.8 & 123.9 \\
\hline $\mathrm{Pb}$ & 3.69 & & 4.87 & 5.43 & 6.53 & 6.63 & 4.49 & 2.73 & 2.91 & 5.52 & 4.72 & 6.39 \\
\hline $\mathrm{Pr}$ & 4.6 & & 12.9 & 13.6 & 15.4 & 17.7 & 11.6 & 8.2 & 8.0 & 14.1 & 12.4 & 16.3 \\
\hline $\mathrm{Nd}$ & 20.1 & & 48.6 & 49.9 & 59.8 & 70 & 46.4 & 32.5 & 32.2 & 54.2 & 49.2 & 63.8 \\
\hline $\mathrm{Sr}$ & 348 & & 653 & 312 & 614 & 580 & 588 & 523 & 513 & 632 & 631 & 658 \\
\hline $\mathrm{Zr}$ & 143 & & & & & & & & & & & \\
\hline $\mathrm{Hf}$ & 3.57 & & 7.44 & 7.26 & 8.73 & 10.37 & 6.9 & 4.7 & 4.89 & 7.68 & 7.32 & 8.13 \\
\hline $\mathrm{Sm}$ & 4.76 & & 8.89 & 9.16 & 11.42 & 13.77 & 9.10 & 6.36 & 6.72 & 10.36 & 9.42 & 12.23 \\
\hline Eu & 1.65 & & 2.70 & 2.77 & 3.52 & 3.98 & 2.86 & 2.16 & 2.17 & 3.24 & 2.98 & 3.75 \\
\hline Gd & 4.79 & & 8.54 & 8.80 & 10.41 & 13.16 & 8.20 & 6.24 & 6.10 & 9.32 & 8.21 & 11.38 \\
\hline Tb & 0.74 & & 1.11 & 1.19 & 1.43 & 1.78 & 1.14 & 0.86 & 0.85 & 1.29 & 1.13 & 1.64 \\
\hline Dy & 4.07 & & 6.10 & 6.15 & 8.20 & 9.96 & 6.59 & 4.84 & 4.90 & 7.13 & 6.42 & 9.08 \\
\hline Ho & 0.74 & & 1.06 & 1.09 & 1.44 & 1.73 & 1.16 & 0.85 & 0.87 & 1.26 & 1.14 & 1.61 \\
\hline Y & 18.4 & & 29.8 & 30.1 & 37.6 & 46.8 & 30.4 & 22.4 & 21.9 & 32.8 & 28.1 & 42.3 \\
\hline Er & 1.83 & & 2.85 & 2.99 & 3.71 & 4.52 & 2.92 & 2.15 & 2.25 & 3.18 & 2.88 & 4.22 \\
\hline $\mathrm{Tm}$ & 0.24 & & 0.34 & 0.36 & 0.47 & 0.57 & 0.36 & 0.27 & 0.27 & 0.41 & 0.35 & 0.55 \\
\hline Yb & 1.37 & & 2.2 & 2.27 & 3.04 & 3.73 & 2.34 & 1.73 & 1.73 & 2.57 & 2.22 & 3.58 \\
\hline Lu & 0.2 & & 0.32 & 0.33 & 0.42 & 0.52 & 0.34 & 0.25 & 0.25 & 0.36 & 0.32 & 0.51 \\
\hline${ }^{4} \mathrm{He}$ ccSTP/g & & & 1.36E-08 & 5.56E-09 & & & $6.24 \mathrm{E}-09$ & 1.35E-09 & $6.06 \mathrm{E}-08$ & & $9.78 \mathrm{E}-09$ & $\begin{array}{l}\text { coarse: } 4.3 \mathrm{E}-09 \\
\text { fine: } 5.5 \mathrm{E}-10\end{array}$ \\
\hline${ }^{3} \mathrm{He} /{ }^{4} \mathrm{He}(\mathrm{Ra})$ & & & 8.6 & 7.7 & & & 9.3 & 8.0 & 8.2 & & 9.0 & $\begin{array}{c}\text { coarse: } 11.8 \\
\text { fine: } 13.3\end{array}$ \\
\hline Os, ppt & & & 48.7 & 53.2 & & & 31.1 & 41.6 & 95.0 & 85.1 & & \\
\hline${ }^{187} \mathrm{Os} / /^{188} \mathrm{Os}$ & & & 0.1364 & 0.1432 & & & 0.1377 & 0.1393 & 0.1408 & 0.1342 & & \\
\hline${ }^{143} \mathrm{Nd} / /^{144} \mathrm{Nd}$ & 0.512585 & & 0.512447 & 0.512435 & 0.512533 & 0.512716 & 0.512589 & 0.512538 & 0.512521 & 0.512518 & 0.512518 & 0.512590 \\
\hline${ }^{87} \mathrm{Sr} \mathbf{8}^{86} \mathrm{Sr}$ & 0.704485 & & 0.705243 & 0.705220 & 0.704748 & 0.703702 & 0.704824 & 0.704633 & 0.704639 & 0.704975 & 0.704999 & 0.704687 \\
\hline${ }^{206} \mathrm{~Pb} /{ }^{204} \mathrm{~Pb}$ & 17.732 & & 17.630 & 17.611 & 17.789 & 18.054 & 17.833 & 17.900 & 17.858 & 17.789 & 17.735 & 18.131 \\
\hline${ }^{207} \mathrm{~Pb} / /^{204} \mathrm{~Pb}$ & 15.474 & & 15.460 & 15.461 & 15.492 & 15.506 & 15.494 & 15.494 & 15.478 & 15.487 & 15.474 & 15.515 \\
\hline${ }^{208} \mathrm{~Pb} / /^{204} \mathrm{~Pb}$ & 38.438 & & 38.936 & 38.912 & 38.970 & 39.064 & 38.982 & 38.976 & 38.939 & 38.975 & 38.943 & 38.926 \\
\hline
\end{tabular}

Data in italics are previously published in Eiler et al. (1995) where NA indligtes "present but not analyzed". ${ }^{*} \mathrm{He} /{ }^{4} \mathrm{He}$ on sample PIT-16, was measured twice, on coarse $\left(11.8 \mathrm{Ra} ; 4.3^{\star} 10^{-9} \mathrm{cc} \mathrm{STP} / \mathrm{g}\right)$ and fine $\left(13.3 \mathrm{Ra} ; 5.5^{\star} 10^{-10}\right)$ olivine fractions, to verify the elevated ${ }^{3} \mathrm{He} /{ }^{4} \mathrm{He}$ ratio. 
Table 2: Olivine analyses for 65DS-4.

\begin{tabular}{|l||cccccccc|}
\hline & $\begin{array}{c}\mathrm{SiO}_{2} \\
\text { (wt.\%) }\end{array}$ & $\begin{array}{c}\mathbf{F e O}_{\mathbf{T}} \\
\text { (wt. } \%)\end{array}$ & $\begin{array}{c}\mathbf{C a O} \\
\text { (wt.\%) }\end{array}$ & $\begin{array}{c}\text { MgO } \\
\text { (wt.\%) }\end{array}$ & $\begin{array}{c}\text { MnO } \\
\text { (wt.\%) }\end{array}$ & $\begin{array}{c}\text { NiO } \\
\text { (wt.\%) }\end{array}$ & Total & $\mathbf{X}_{\text {Fo }}$ \\
\hline \hline 65DS04-ol1-1 & 40.20 & 14.50 & 0.24 & 45.50 & 0.18 & 0.24 & 100.87 & 84.8 \\
65DS04-ol1-2 & 40.56 & 14.21 & 0.26 & 45.18 & 0.21 & 0.26 & 100.69 & 85.0 \\
65DS04-ol1-3 & 40.82 & 14.12 & 0.26 & 45.18 & 0.16 & 0.24 & 100.77 & 85.1 \\
65DS04-ol1-4 & 40.47 & 14.41 & 0.25 & 45.25 & 0.22 & 0.28 & 100.89 & 84.8 \\
65DS04-ol1-5 & 40.20 & 14.96 & 0.25 & 44.71 & 0.18 & 0.29 & 100.58 & 84.2 \\
65DS04-ol1-6 & 40.45 & 14.89 & 0.24 & 44.73 & 0.18 & 0.22 & 100.71 & 84.3 \\
65DS04-ol1-7 & 40.11 & 14.45 & 0.25 & 45.03 & 0.21 & 0.22 & 100.27 & 84.8 \\
65DS04-ol1-8 & 40.51 & 14.56 & 0.26 & 44.88 & 0.18 & 0.25 & 100.63 & 84.6 \\
65DS04-ol2-1 & 40.44 & 14.53 & 0.26 & 45.10 & 0.17 & 0.23 & 100.74 & 84.7 \\
65DS04-ol2-2 & 40.14 & 14.47 & 0.26 & 44.96 & 0.20 & 0.25 & 100.28 & 84.7 \\
65DS04-ol2-3 & 39.94 & 14.46 & 0.28 & 44.66 & 0.18 & 0.27 & 99.78 & 84.6 \\
65DS04-ol2-4 & 40.32 & 14.72 & 0.27 & 45.18 & 0.20 & 0.24 & 100.93 & 84.6 \\
\hline
\end{tabular}

$\mathrm{X}_{\mathrm{Fo}}=(\mathrm{n}(\mathrm{MgO}) /(\mathrm{n}(\mathrm{MgO})+\mathrm{n}(\mathrm{FeO})))^{*} 100$, where $\mathrm{n}=$ number of moles;

Multiple spots were measured on two olivine grains. The grains were designated as ol1 ( $n=8$ spots) and ol2 ( $n=4$ spots). 